\title{
مصطلحُ الالتزام في النقد الإسلامي المعاصر: دراسةٌ في المفهوم ومجالات الاستخدام
}

سيد سيد عبد الرازق

مقدمة:

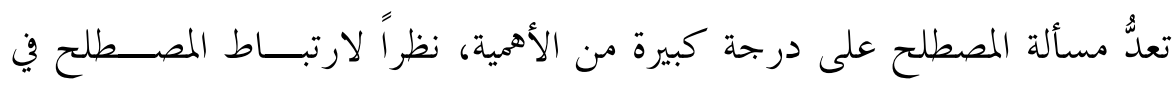

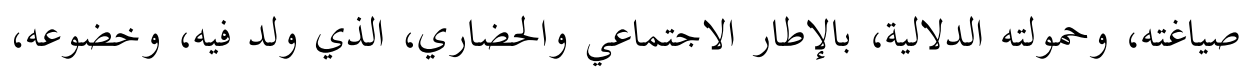

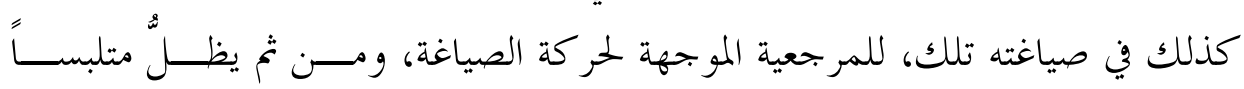

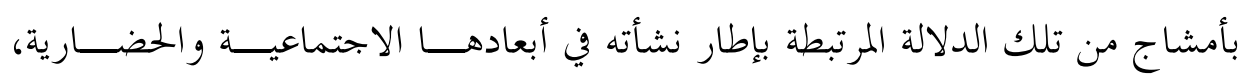

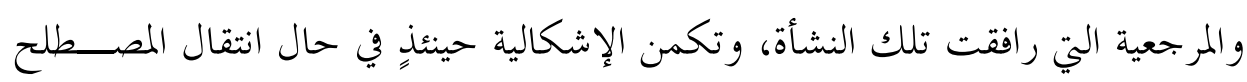

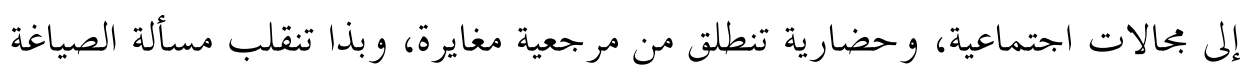

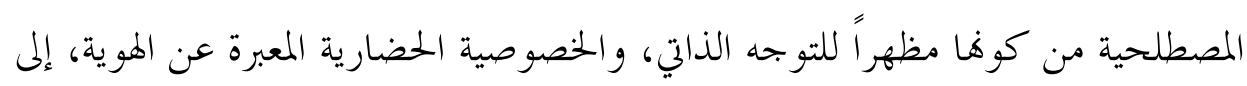

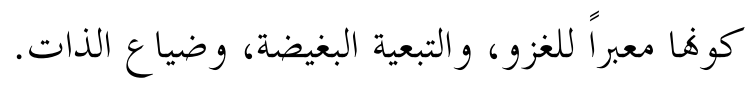

ومصطلح الالتزام في النقد المعاصر، وليدُ بيئة ثقافية، ومناخ حضاري مغاير غخيطنا

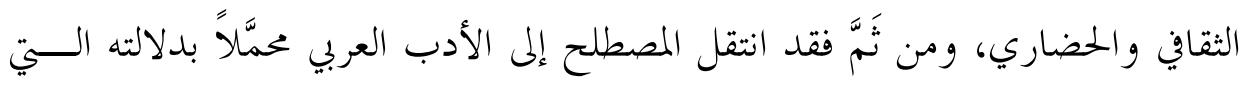

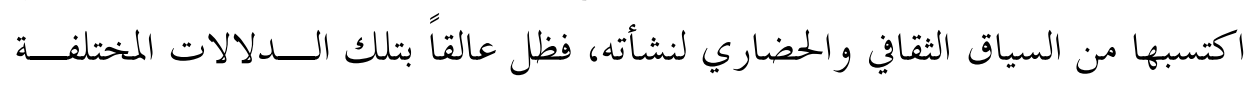

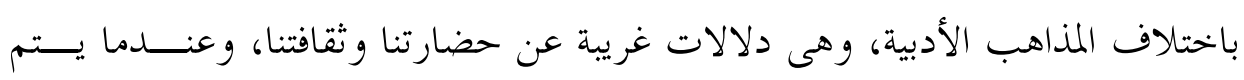

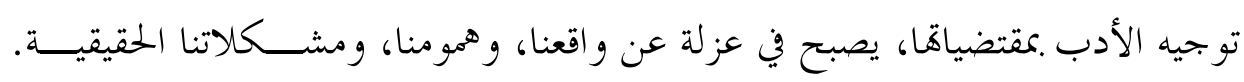

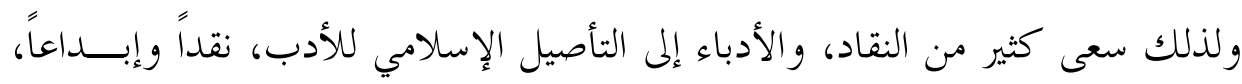

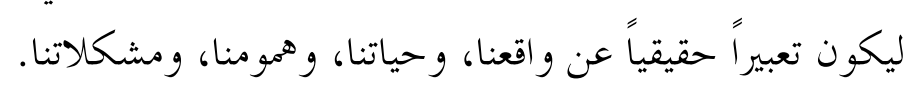

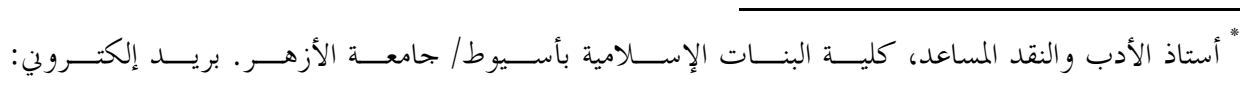
said_abdelrazek_1@yahoo.com 
و في دائرة هذا التأصيل، جرى استخدام مصطلح الالتزام، لدى الناقد الإســلامي،

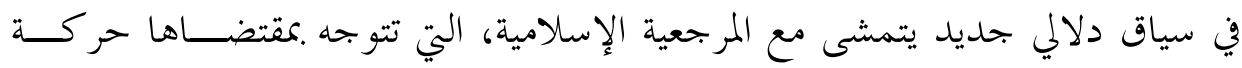

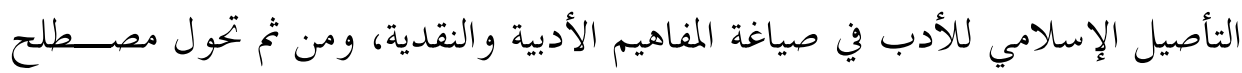
الالتزام إلى الدلالة على التمسك .متطلبات المرجعية الإسلامية في الصياغة الأدبية، تعبيراً عن التجارب الإنسانية الخاصة و العامة.

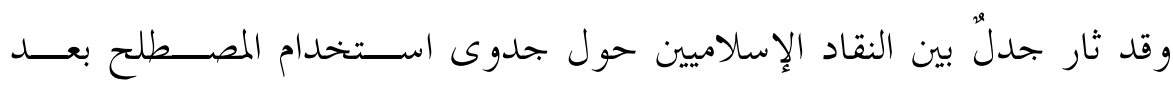
استرفاده من محيطات مضادة، وما إذا كانت هناك ضرورة لاستخدامه داخل سياقات

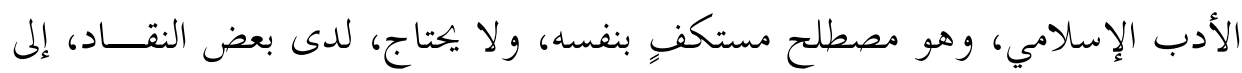
مصطلحات أخرى تحدد عمومه، فالأدب الإسلامي يحمل ضمنياً معنى الالتـــزام تجـــــاه المرجعية الإسلامية في مبادئها الكلية.

سعياً إلى تحديد الموقف الصحيح من مصطلح الالتزام، وجدو اه في الإجراء النقدي الإسلامي، كان تركيز هذا البحث على محاولة حصر المجالات الســياقية لاســتخدام

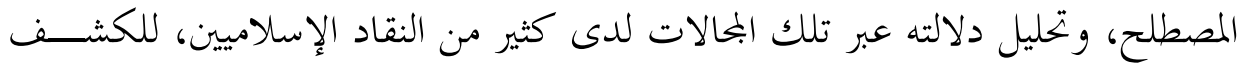
عن الدلالات الجمديدة للمصطلح، تلك التي تواكب متطلبات المرجعية الموجهة لحركة التأصيل الإسلامي للأدب وتتجاوب مع معطياها.

قام البحث باستقراء بحالات استخدام المصطلح، لدى النقاد الإسلاميين، وفحص دلالتها غير معزولة عن سياقها الذي وردت فيه، فهو منهج استقرائي تحليلــي، يقـــوم على الربط بين المصطلح، و سياق استخدامه، ومرجعيته. وحرص البحث كذلك على إبراز الدلالة الإسلامية للمصـــلح عنـــــ النتـــاد، وتأكيدها، ومن ثَمَّ بيان أهمية استخدامه في المعايرة النقدية، و الضرورات وات والقيم العملية

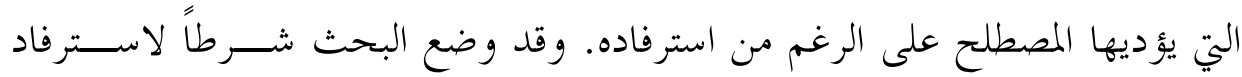

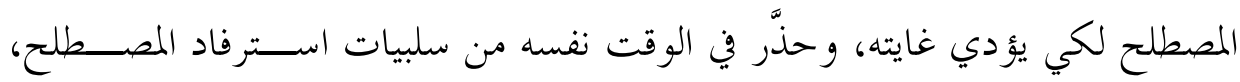




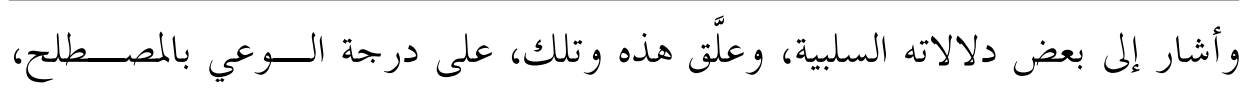
و المتطلبات المرجعية التي ينطلق منها الناقد.

\section{أولاً: المصطلحُ في سياقه الحضاري والمذهبي}

جرى استخدام مصطلح الالتزام في ميادين النقــــــ الأدبي المعاصــر، وأوســـاطه المختلفة، باختلاف المذهبيات و المبادئ التي تقوم عليها المذاهب النقدية الحديثة، فكان لكل مذهب نقدي من تلك المذاهب، موقفه المبنى على فهمه الخاص لمصطلح الالتــزام

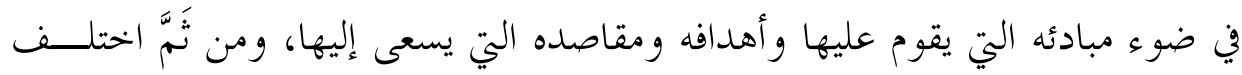
الموقف من مصطلح الالتزام، و اختلف كذلك مفهومه لدى هذه المذاهب التي جرى في في

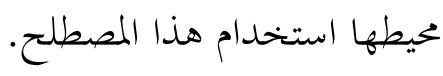

\section{ا ـ دلالة المصطلح في المذهب الواقعي الاشتراكي:}

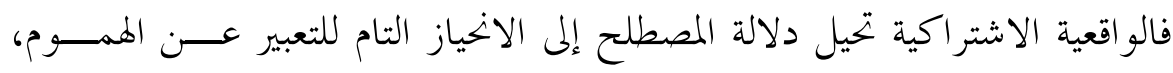

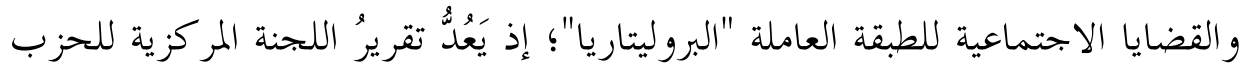

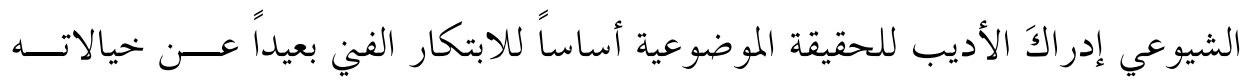

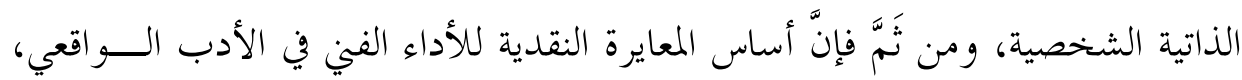

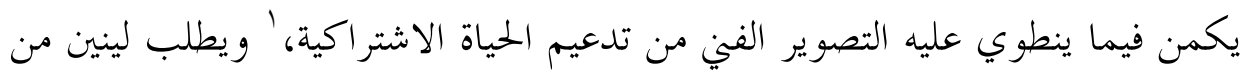

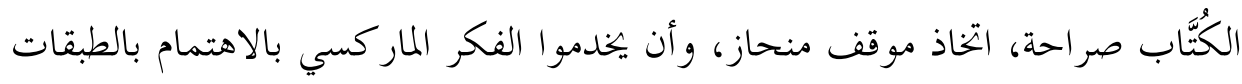

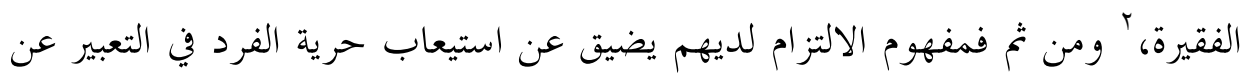

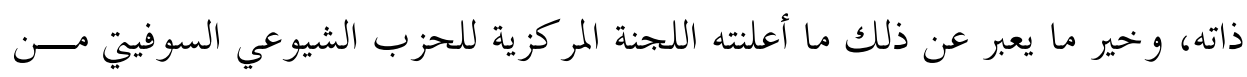

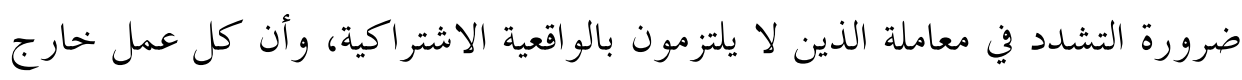
عن ذلك إنما هو ضد الأخلاق.

' عيد، رجاء. فلسفة الالتزام في النقد الأدبي بين النظرية والنطبيق، الإسكندرية: منشــأة المعـــارف، 919 ام، صדr

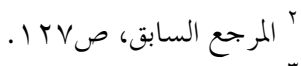

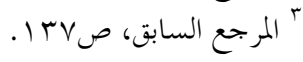




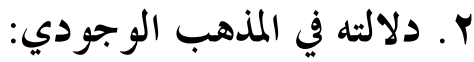

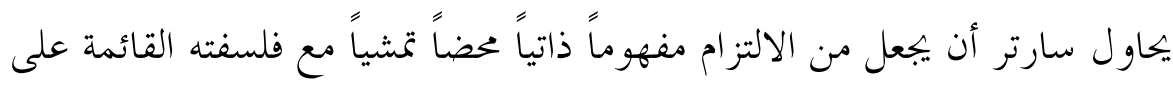

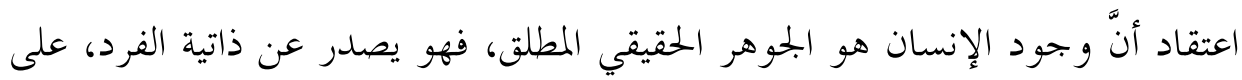
النقيض مما تقول به المادية الجدلية.

ومن ثم تنصرف دلالة الالتزام الوجودي إلى اتخاذ الأدب وسيلة للتعبير عن الرؤى

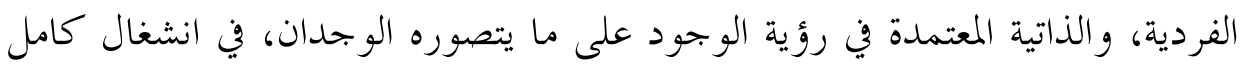

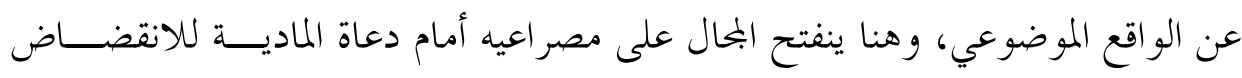

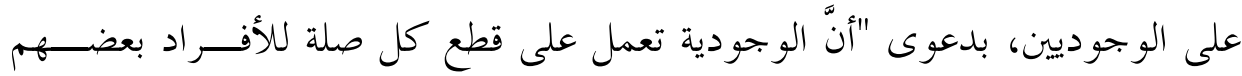

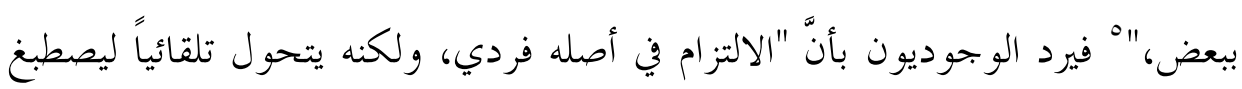

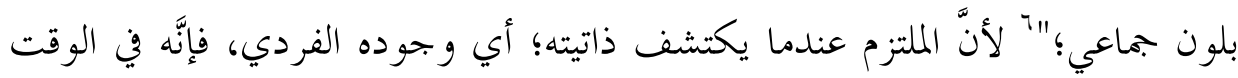

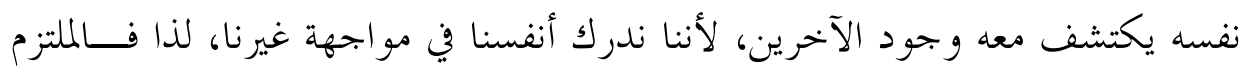

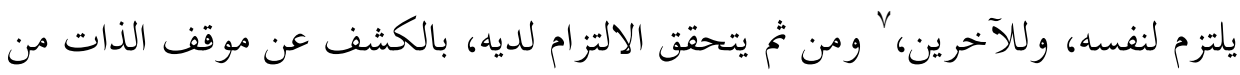

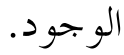

هكذا يتلون مفهوم الالتزام بلون الفلسفة التي يقوم عليها المذهب الأدبي، ولســـا.

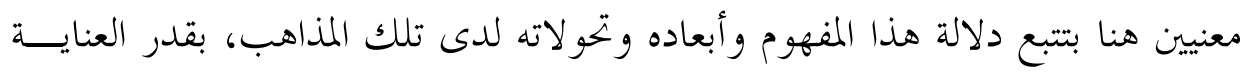

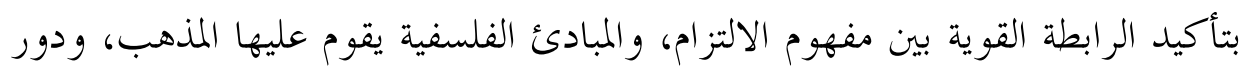

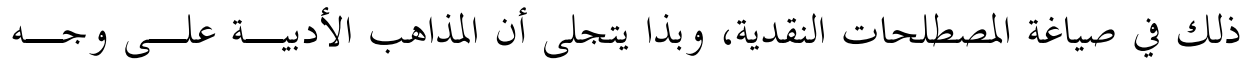
العموم، و كل ما يتو الد في محاضنها من مفاهيم، ومصطلحات، ومناهج، وإجر اءات هو لهو وليد سياق فلسفي، وحضاري خاص.

$$
\begin{aligned}
& \text { ؛ المرجع السابق، صع ا. }
\end{aligned}
$$

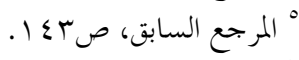

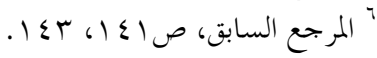

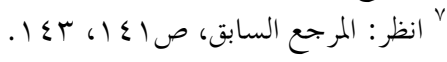




\section{r. استيراد المناهج الغربية في النقد العربي:}

وغير بعيد عن الإدراك أن الخطاب النقدي العربي، منذ بدايات القرن العشــــين

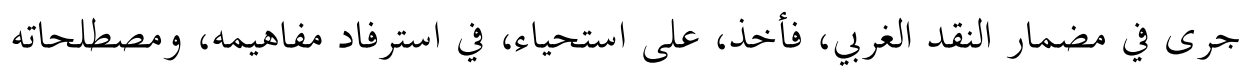

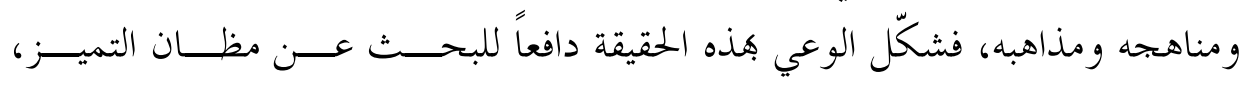

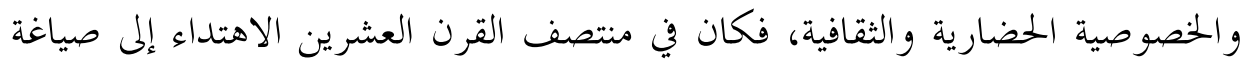

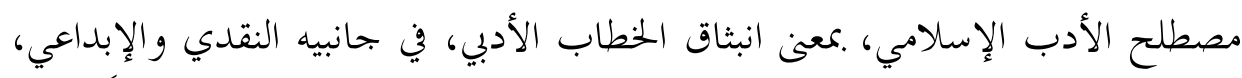

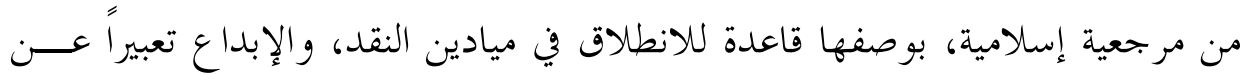
كل ما يتصل بحياة الإنسان، الفردية والاجتماعية، في مجيع ميادينها.

\section{ع. استرفاد المصطلح في السياق الإسلامي:}

غير أنَّ الاهتداء إلى معالم التميُّز و الخصوصية لدى الناقد الإسلامي، لم يكن ليمنعه

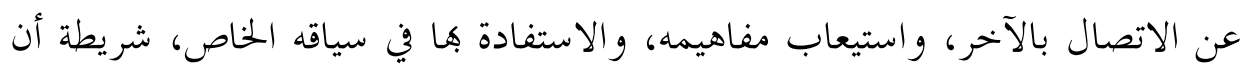

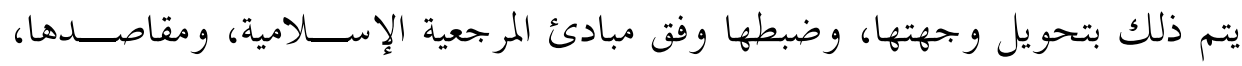
و مقتضياها.

وقد جرى في سياق تلك الاستفادة من الآخر استخدام مصطلح الالتزام في أفــق

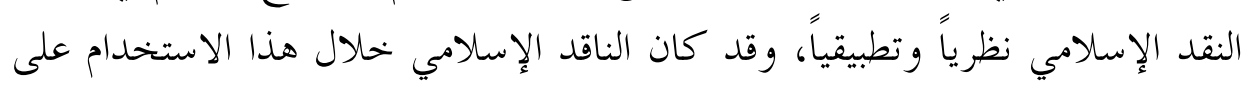

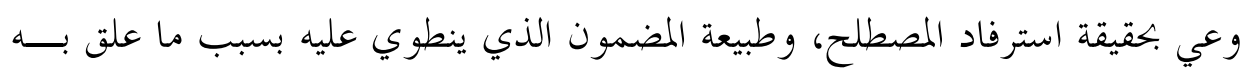

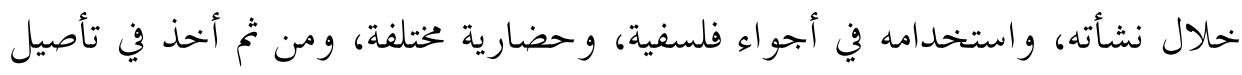

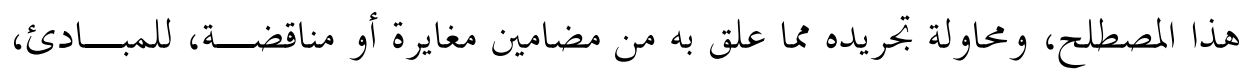
و المقاصد التي يقوم عليها التصور الإسلامي للوجود، تلك التي تشكل مرجعية للتأصيل الإسلامي للأدب.

\section{ثانياً: تأصيل المصطلح إسلامياً}

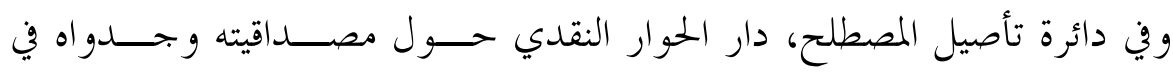

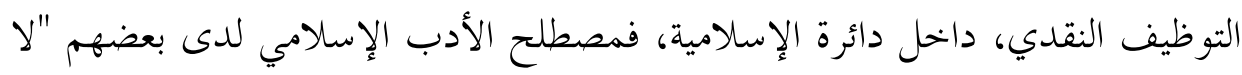




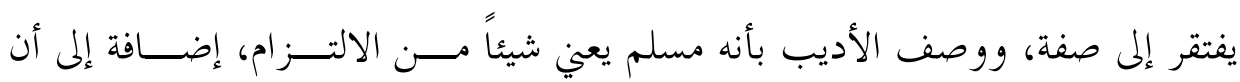

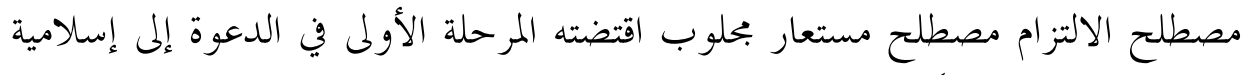

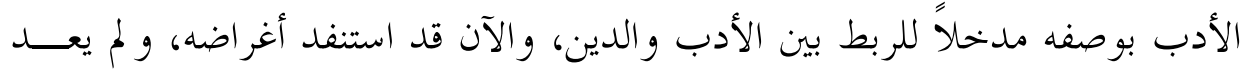

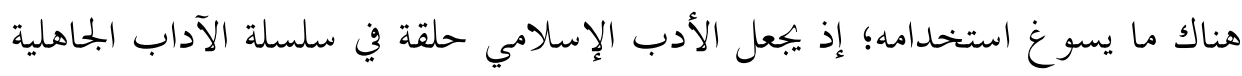

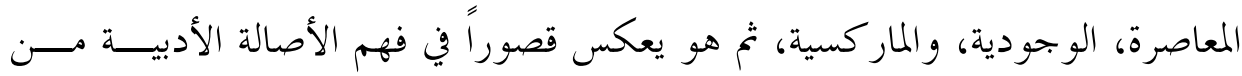

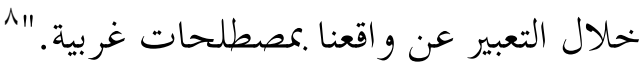

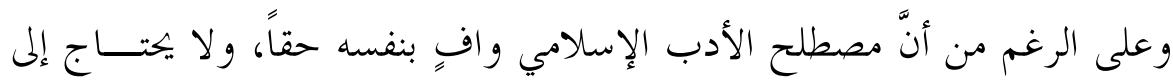

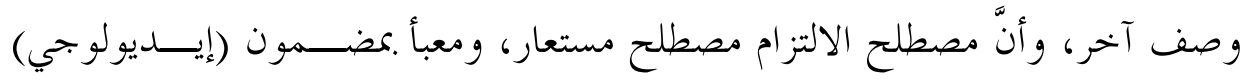

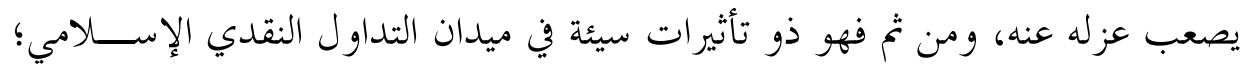

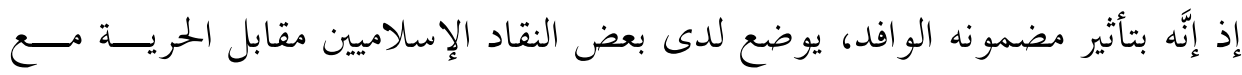

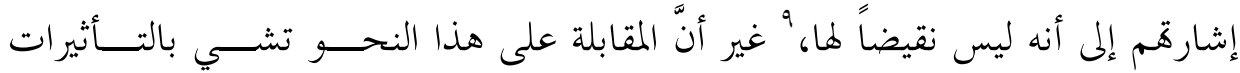

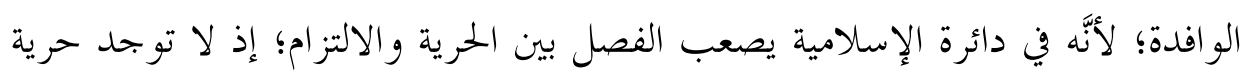

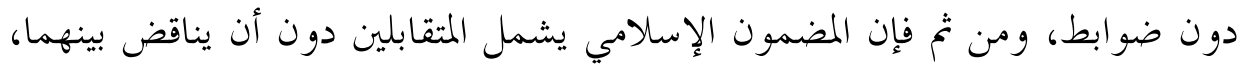

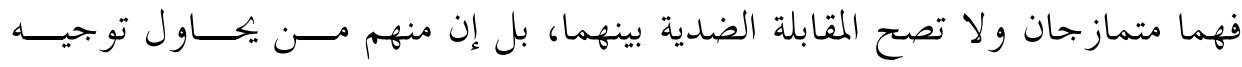

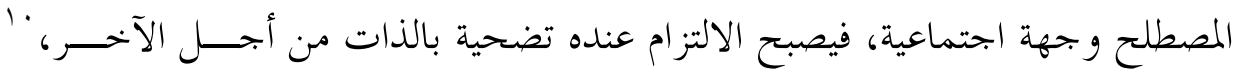

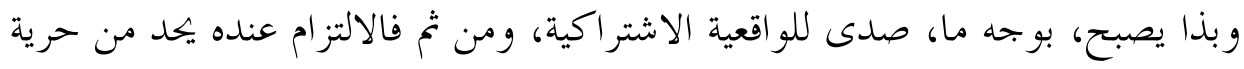

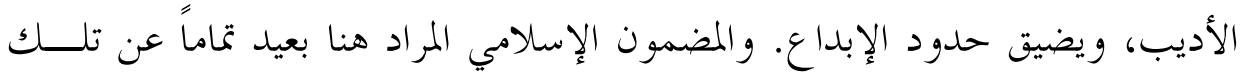

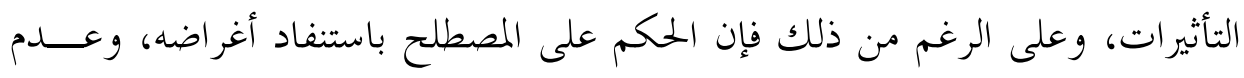

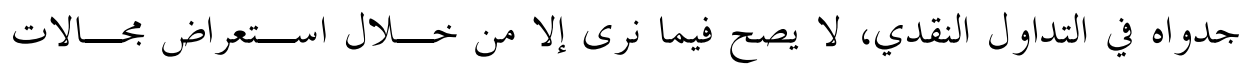

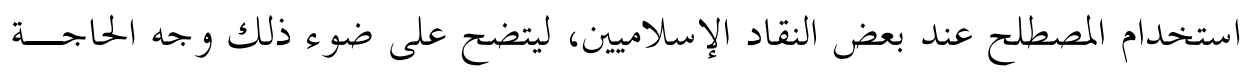

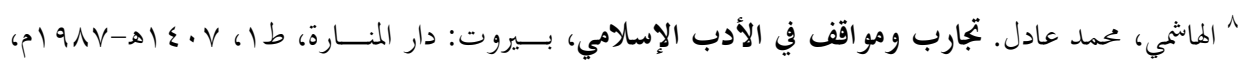

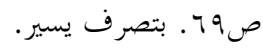

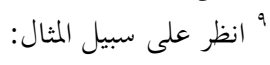

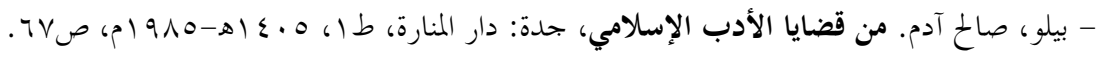

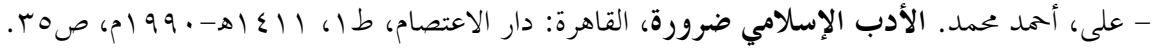

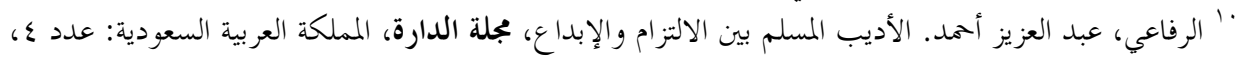




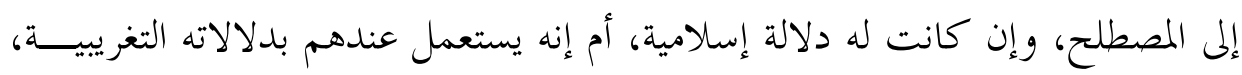

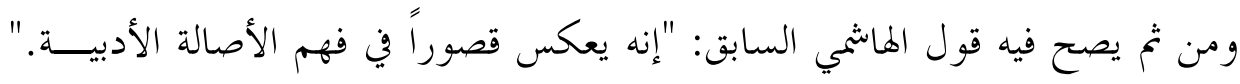
ويمكن ملاحظة جريان حركة التأصيل الإسلامي للمصطلح عبر بحالي التنظير، و التطبيق

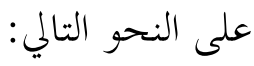

\section{1. بدايات التأصيل:}

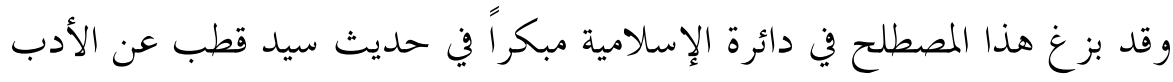

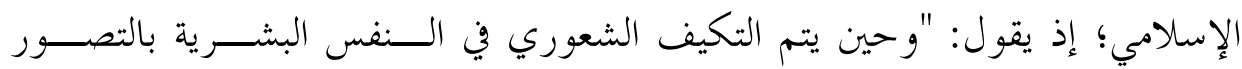

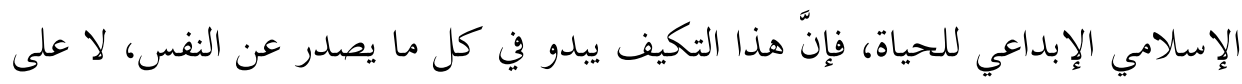

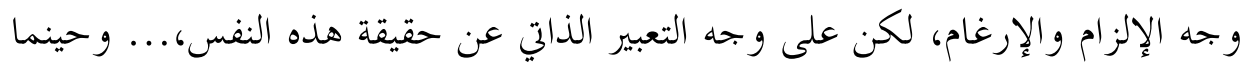

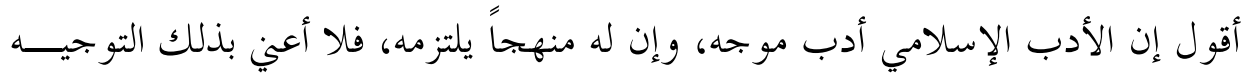

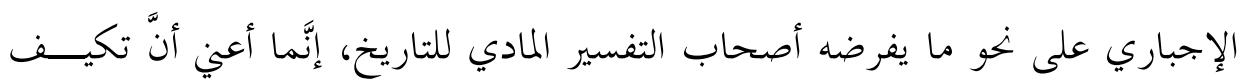

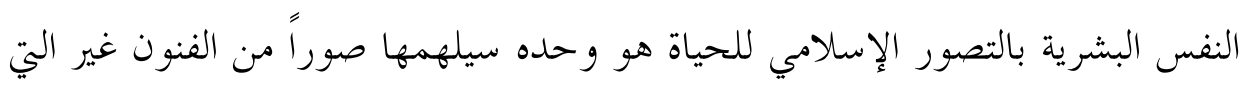

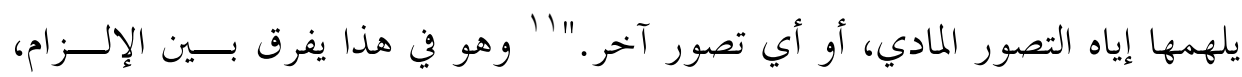

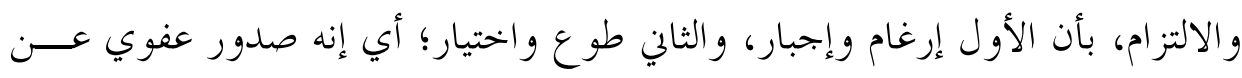

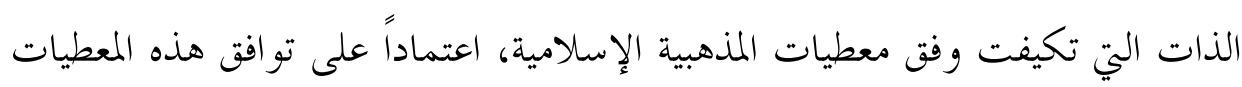

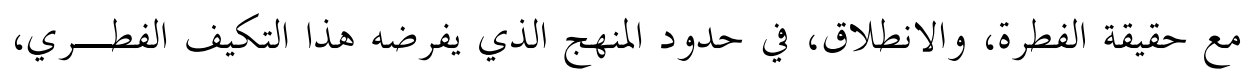

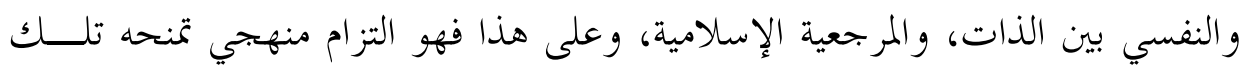

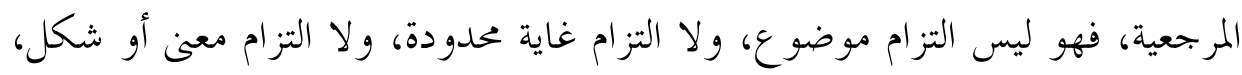

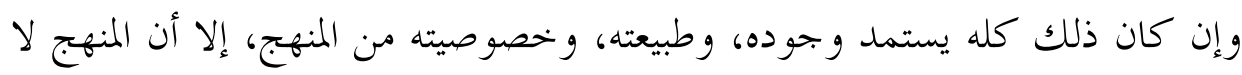

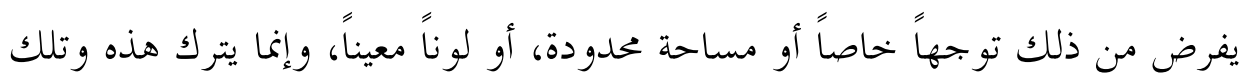

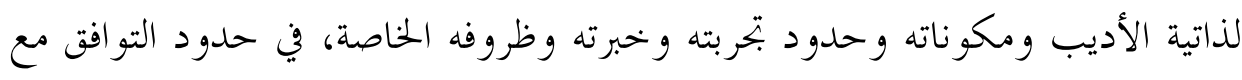


أسسه المذهبية العامة، أو .معنى أوضح يتم الانبثاق الإبداعي عن هذه الأسس بســبب تكيف النفس الإنسانية ها، فيجئ هذا الانبثاق فيضاً ذاتياً منضبطاً بالمنهجية الإسلامية. ويتفق محمد قطب مع شقيقه، حول هذا المعنى للالتزام ويؤ كد ضرورته ووجوبه،

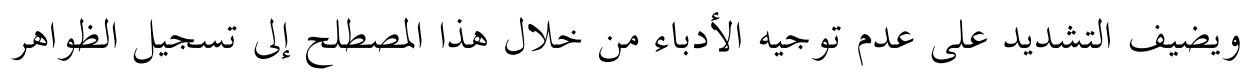

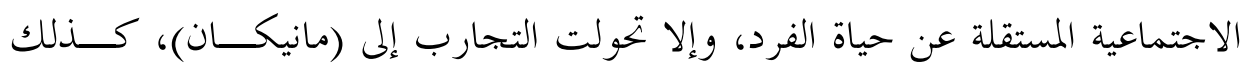

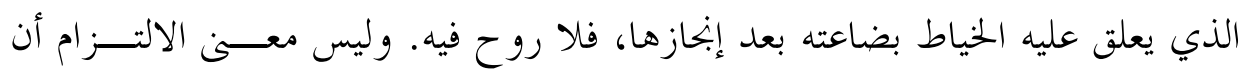

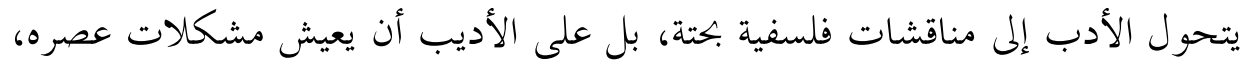

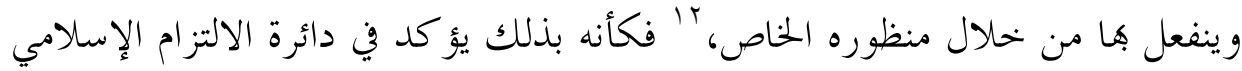

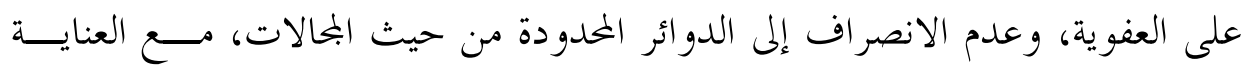
بالروح الأدبية التي تكمن في العناصر الجمالية.

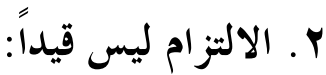

اهتم بنيب الكيلاني اهتماماً شديداً بهذا المصطلح، واعتنى به عناية كبيرة، وأفرد له

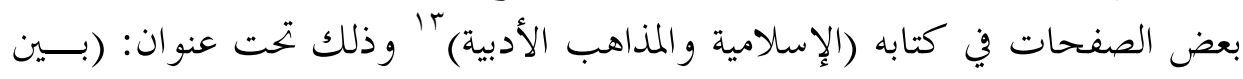

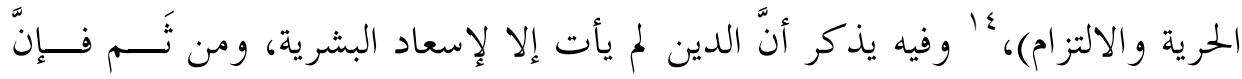

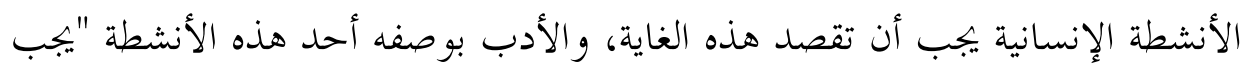

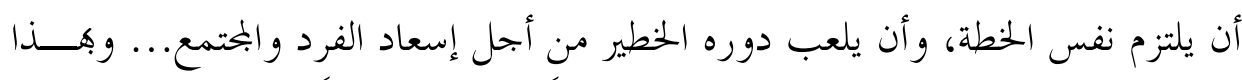

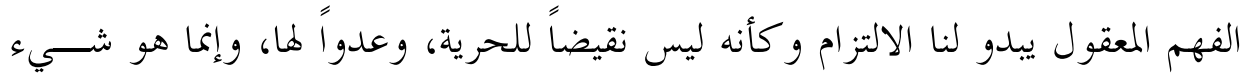

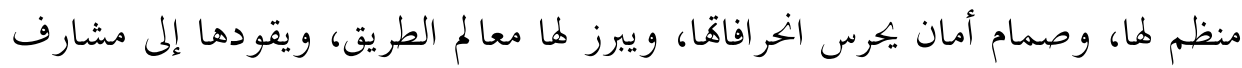

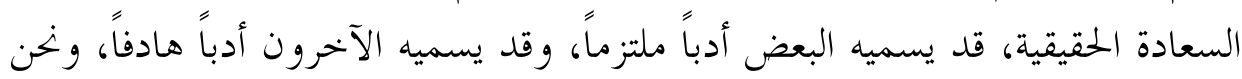
نسميه وجهة نظر إسلامية في الأدب.

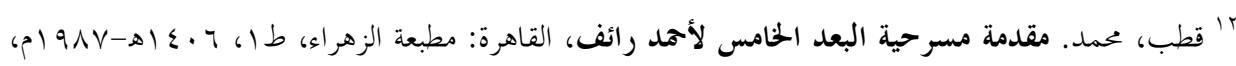

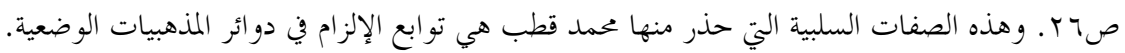

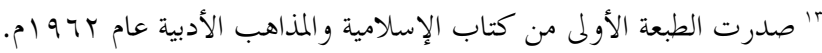

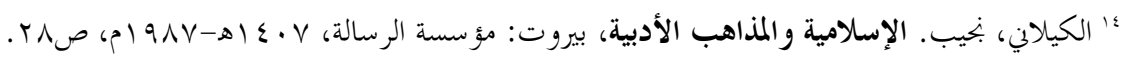

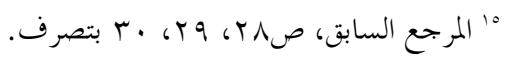


تم يتحدث عن مسؤولية الإنسان المسلم، وهى مسؤولية شاملة للقـــول والفعــل و الحر كة و السكون، و كل الأفراد مسئولون "من هنا كان الأديب المسلم ملتزماً بمنهج شامل في الحياة يعبر عنه بالقول و العمل، ويتمثله في وحدته مع نفسه، وي اندماجه مع

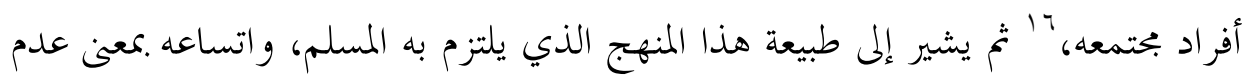

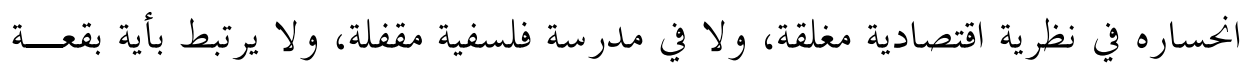

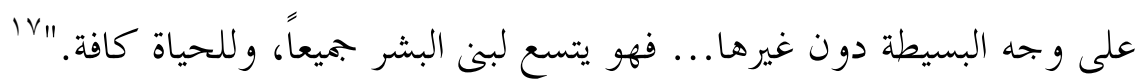

\section{ب. الإلحاح على مسألة الحرية:}

ويعود الكيلالي إلى طرح المسألة من جديد؛؛ ^إذ يـــــــر أن الأدب الإســلامي محكوم في نظرته إلى الحياة و الكون و المخلوقات بالتصور الإسلامي، والالتزام العقدي،

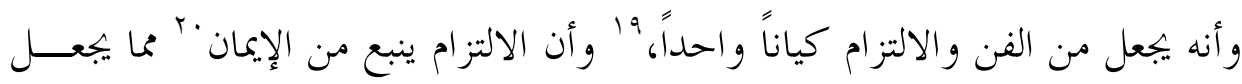
التجربة بتحئ وفق شروطه، وضوابطه التي لا تتعارض مع الحرية، فهو التزام نابع مـــن الذات، ومن القناعة، ومن المعتقد الأصيل الذي يعيش الإنسان في رحابه، ويســتظل

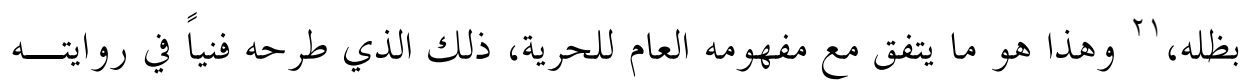

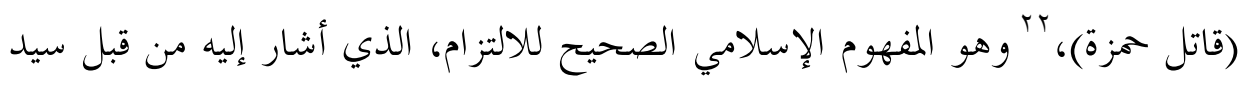
قطب، و شقيقه محمد قطب، التزام متطلبات -وليس التزام غاية- المنهج الإســامي في

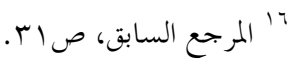

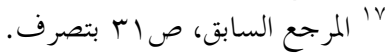

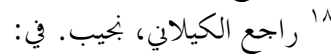

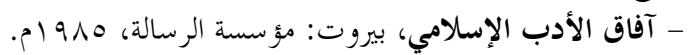

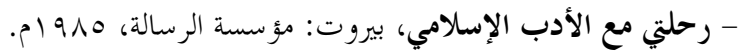

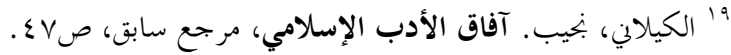

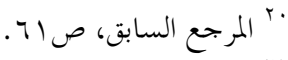

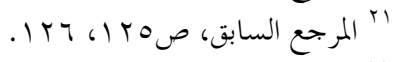

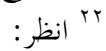

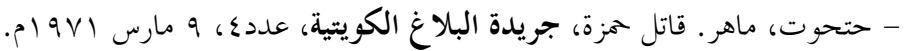

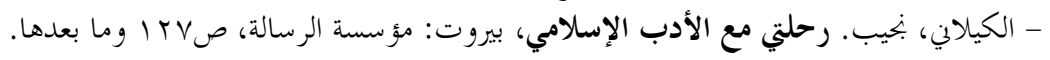




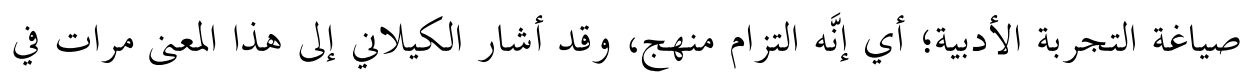

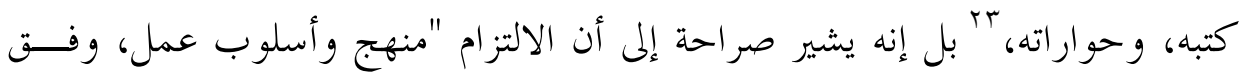
تصور معين. "

تم يضيف الكيلاني إضافات قيمة إلى المعنى المنهجي للالتز ام؛ إذ يؤ كد على حتمية

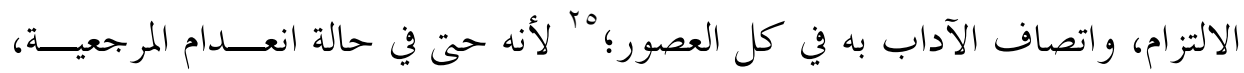

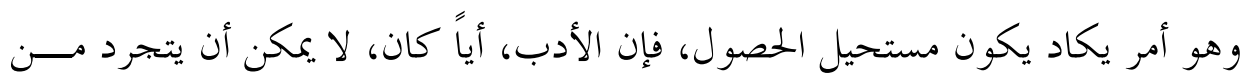

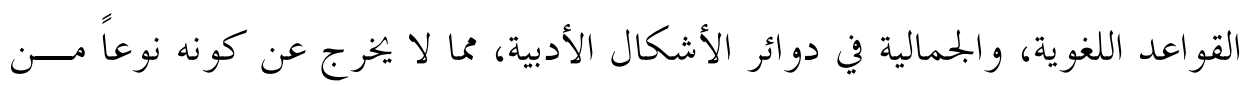

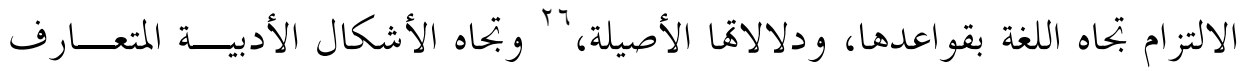

وأخيراً يعبر الكيلاني تعبيراً رائعاً عن عفوية الالتز ام الإسلامي .معنـــاه المنــهجي،

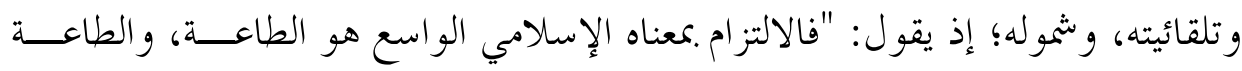
الحقيقية إممان وفرح في قلب المؤمن، وسلوكك مطابق لحقيقة العقيدة، و كل ما يتعلق هما،

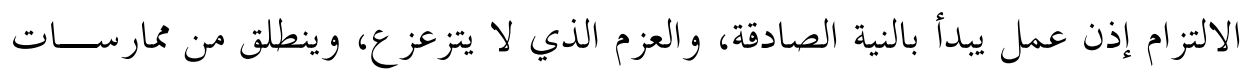

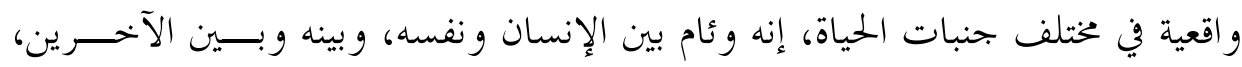

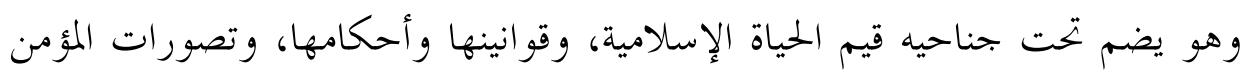
لما يحيط به من كون وسنن، وحيوان، وجماد، ونبات، ويمتد ذلك التصور ليربط الحياة

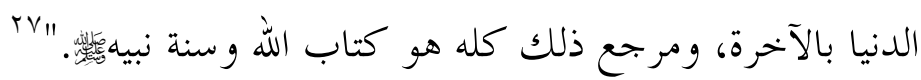

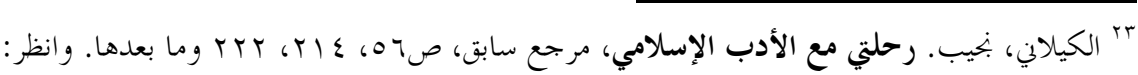

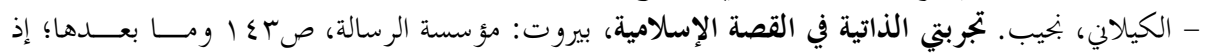

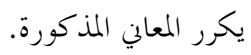

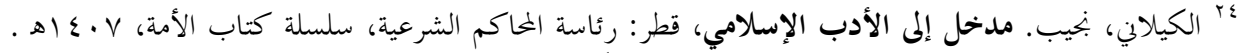

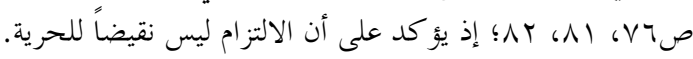

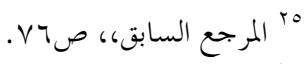

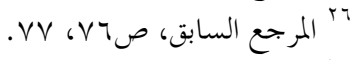

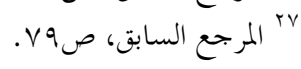


ثم يضيف "الالتزام هنا هو الطاعة، و الطاعة بتحد النور الذي يهلى، والوسيلة التي

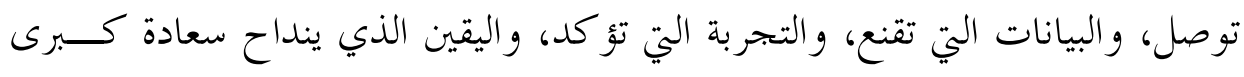

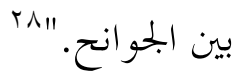

وعلى أساس من هذا المفهوم المنهجي للالتزام، و واستكشاف قيمه العملية، جـــى

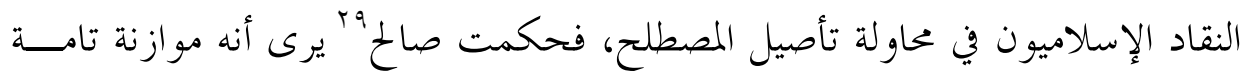

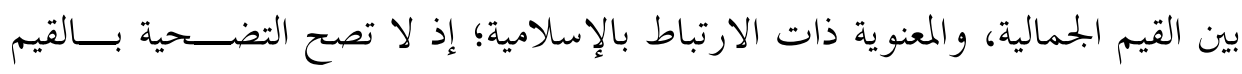

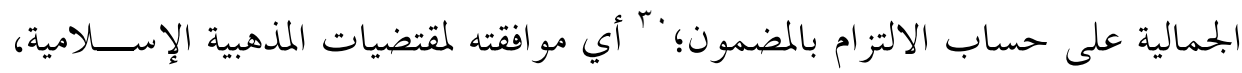

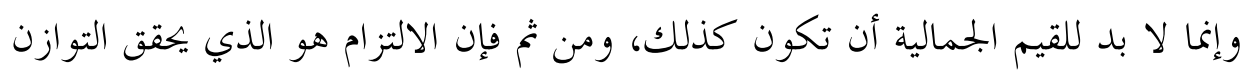
بين هذين الطرفين.

\section{ع. خصوصية المفهوم الإسلامي:}

ويتوصل محمد الرابع الندوي ابّمن خلال اســتقرائه لنمـــاذج الأدب في صــــر الإسلام إلى المفهوم الذي قرره النقاد الإسلاميون من قبل، وهو ما عبر عنـــهـ بقولـــهـ:

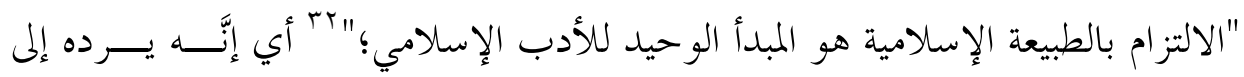

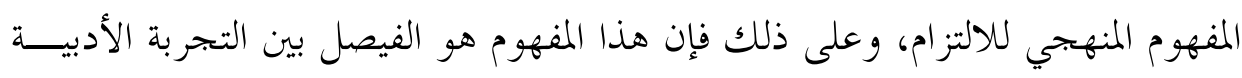
في دائرة الإسلامية، وغيرها من الدو ائر.

أما عبد الباسط بدر "فيستخدمه .معناه المنهجي؛ بَّب أي الالتزام .متطلبات المرجعيـــة الإسالامية في الصياغة والتعبير، وهو هذذا يدل على ضرورة المصطلح في المعيار النقدي،

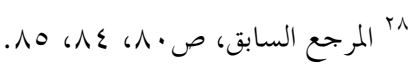

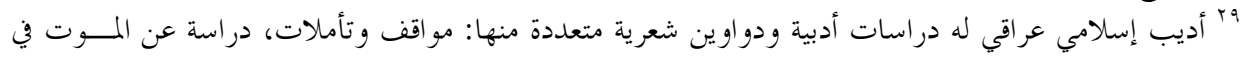

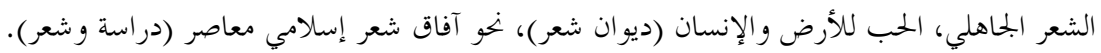

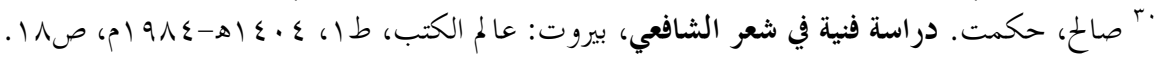

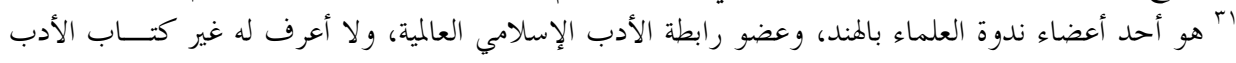

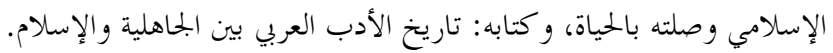

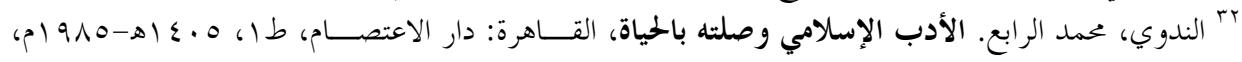

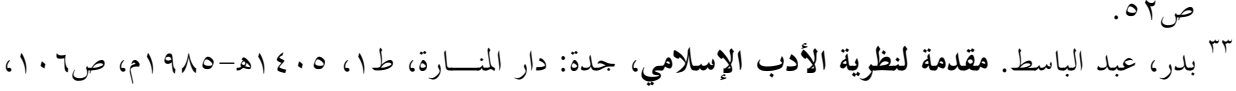




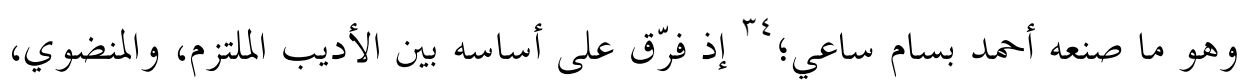

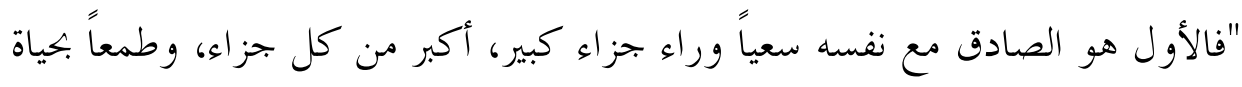
أخرى سرمدية، لا تقارن هـا حياة الأرض مهما أغرته وتبرجت له، أما الانضوائي فهو الذي ارتضى لنفسه أن ينضوي تحت فكرة دنيوية، أو راية بشرية، أو حزب سياسـي

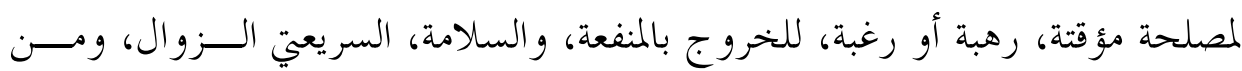
السهل على الانضوائي، وهذه حاله، أن يتزلق بعد ذلك في هوة الانفصام بين حياتــهـ

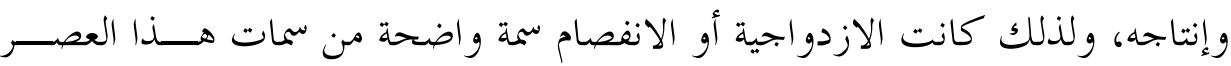

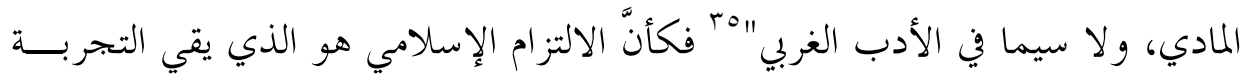

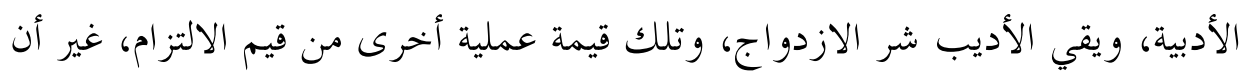
بسام ساعي يستخدم المصطلح (الالتزام) إضافة إلى ذلك في الدلالة علــى التمســكـ

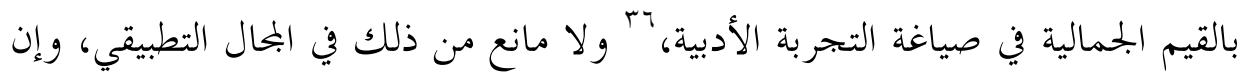

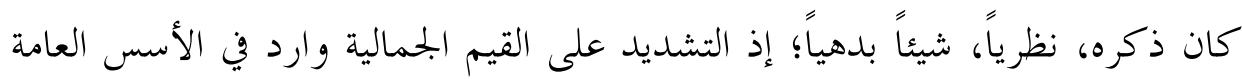
للمذهبية الإسلامية، إضافة إلى كونه غاية من غايات الأدب الإسلامي. ويعبّر عبد الرحمن الباشا تعبيراً دقيقاً ومحدداً عن الدلالة على خصوصية مصطلح الالتزام في مفهومه الإسلامي، فهو عنده "التزام بالإسلام وقيمه، وتصوراته، وتقيد

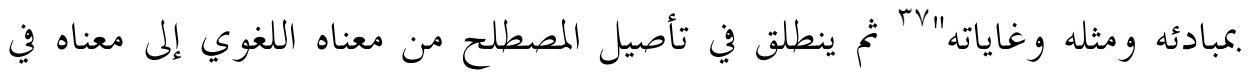
الاصطلاح الأدبي، معرجاً على نشأة المصطلح وسياقاته الحضارية، وصولاً إلى ما أشار

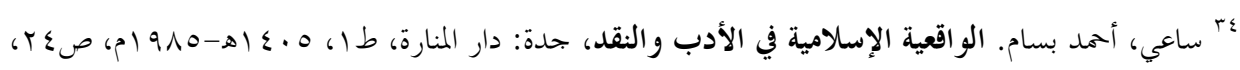
9. 9 . To

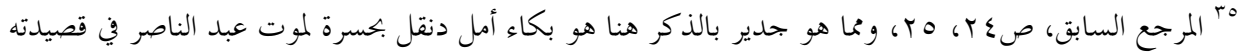

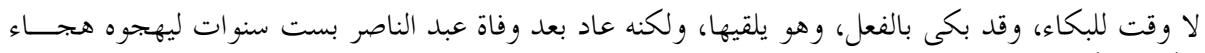

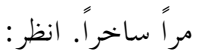

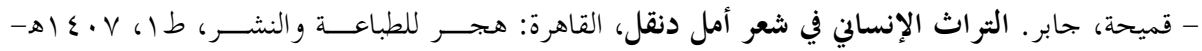

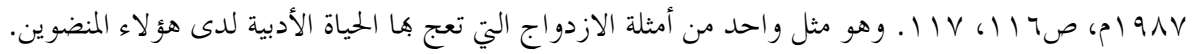

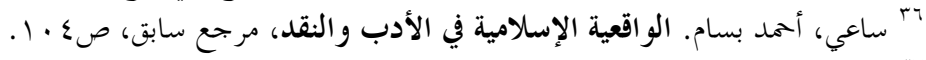

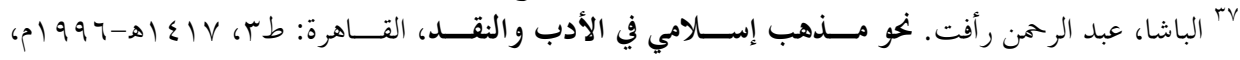


إليه من الدلالة الإسلامية للمصطلح، بوصفها دلالة تمثل خاصية من خصائص الأدب

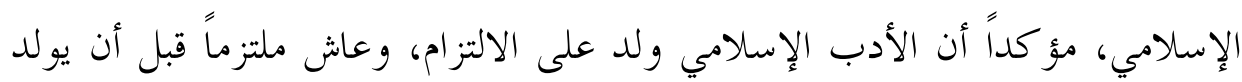
المصطلح في سياق المذاهب الغربية، وهو التزام أرست قواعده الآيات الكريمة:

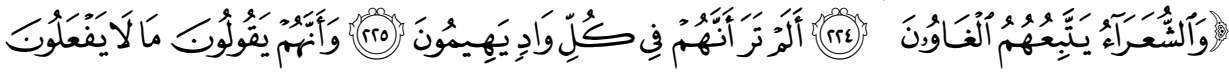

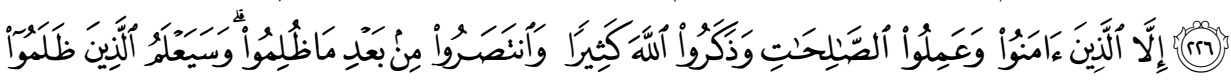

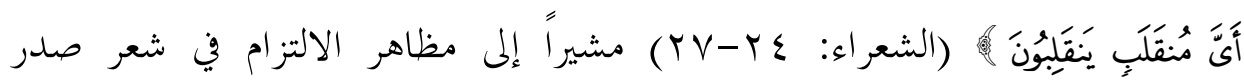

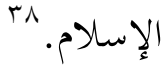

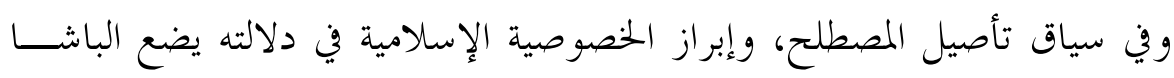

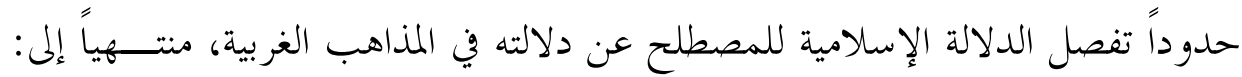

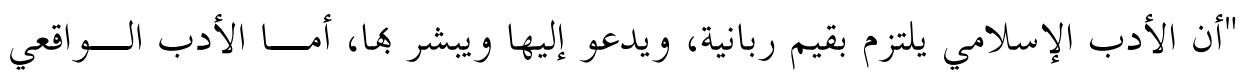
الاشتراكي فهو ملتزم بالواقع كما يحدده الحزب الشيوعي، وأما الأدب الوجودي فهو ملتزم بموقف الفرد، و حريته في اتخاذ الموقف الذي يختاره دون ضابط أو رابط." "ج"r وهو خلال ذلك يكشف عن سلبيات جمة للالتــز ام في مفهـــوم الــــواقعي الاشــتراكي، و الوجودي، بينما تنأى الدلالة الإسلامية للمصطلح عن تلك السلبيات. •؛ ويشير حسن الأمرائ إلى أن المصطلح على الرغم من أنه أثنار كثيراً مـــن الجهـــل

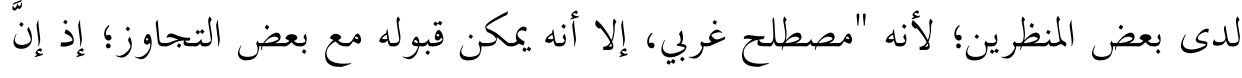
هناك ثلاثة مظاهر متفاوتة للأدب الإسالمي هي:

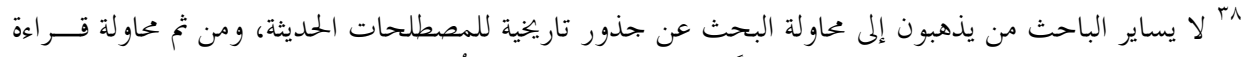

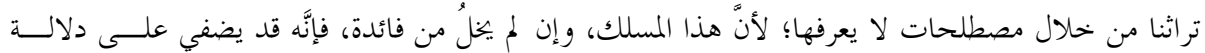

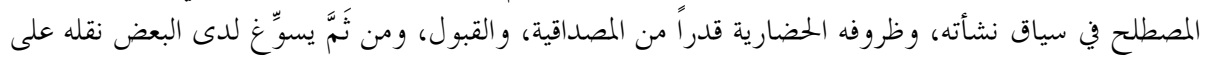

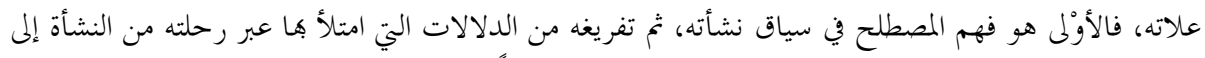

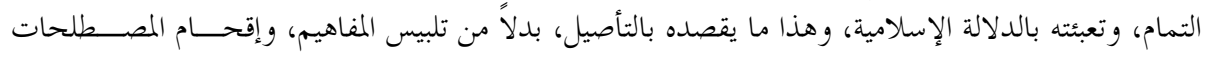

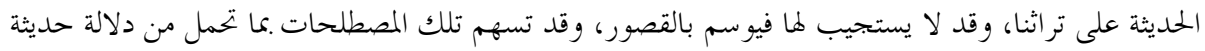

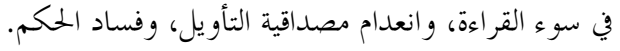

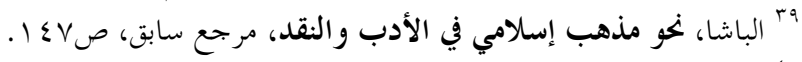

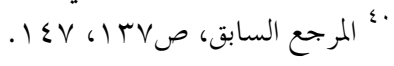




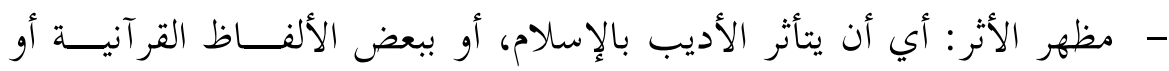

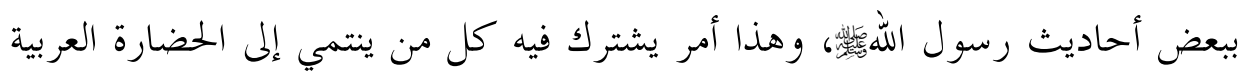

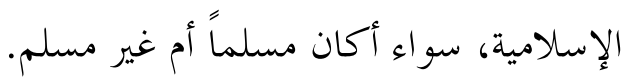
- المظهر الثاني: هو أدب الالتزام أو أدب الدعوة أو الموعظة، وهو الذي شهدناه

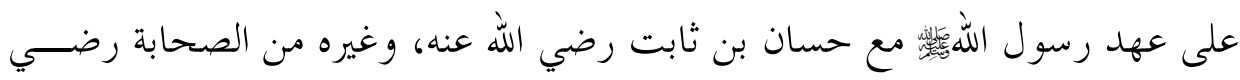

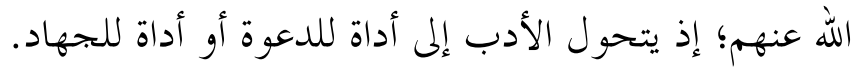
- المظهر الثالث: حين يتحول الأدب إلى رؤية؛ أي إنَّ الإسلامية تظهر في كــــ

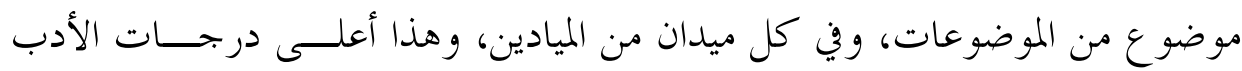

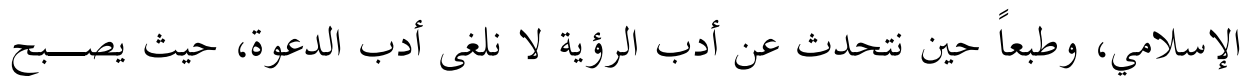

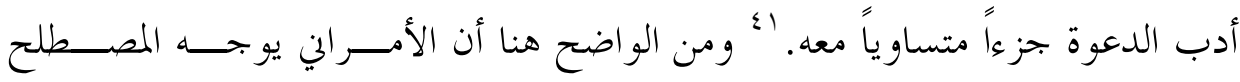

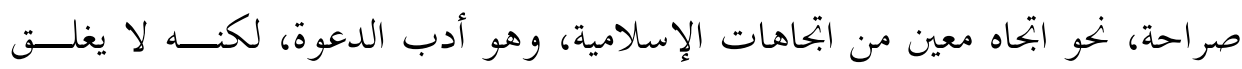

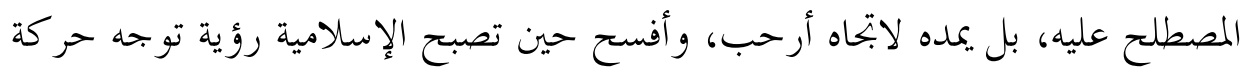

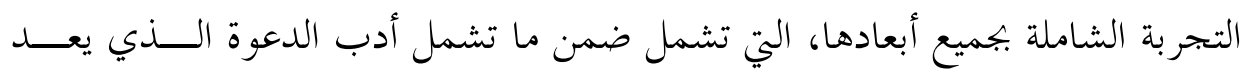

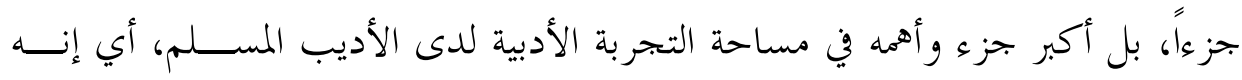

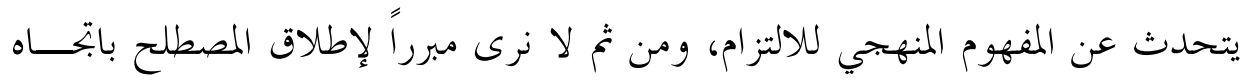

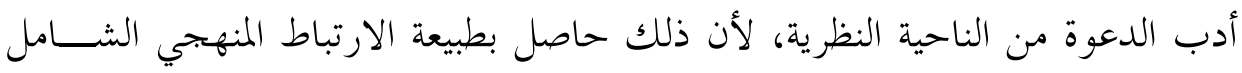

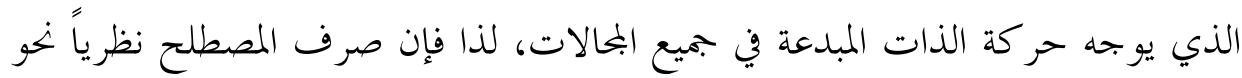

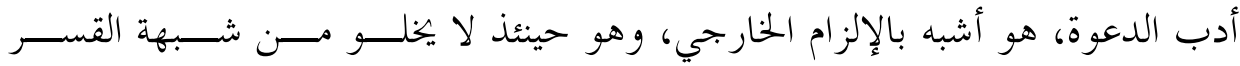

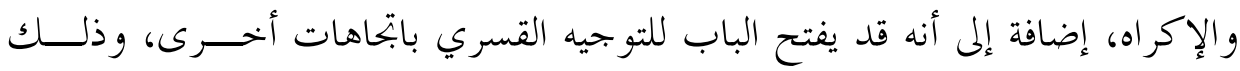

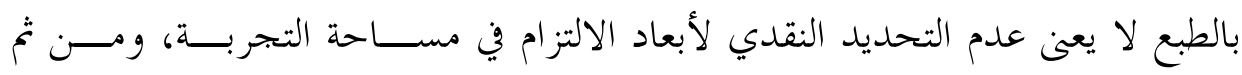

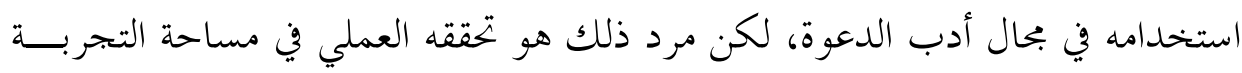

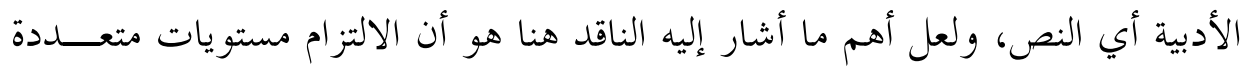

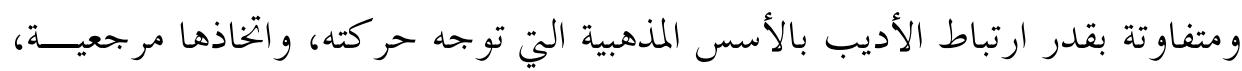

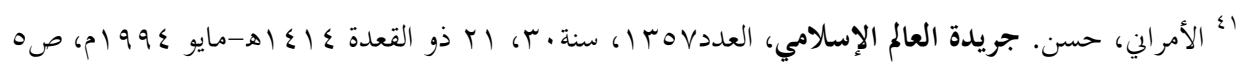

$$
\text { بتصرف. (حوار معه) }
$$


و الوعي .متطلباها، وهو ما يمكن أن يستفاد من محاولة بيلو، على نخو ما ســيتبين، في

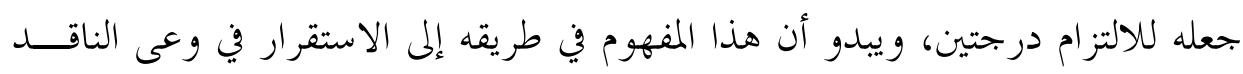
المسلم؛ إذ يقسم العريني روايات الدكتور الكيلاني إلى مستويات ثلاثة بحسب ارتبن ارتباطها بالمذهبية الإسلامية وهي:

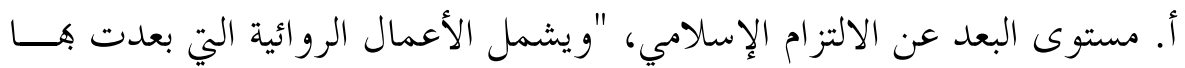

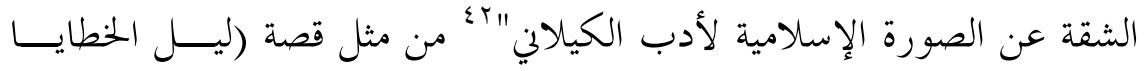
والربيع العاصف.)

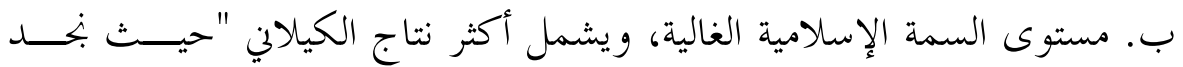

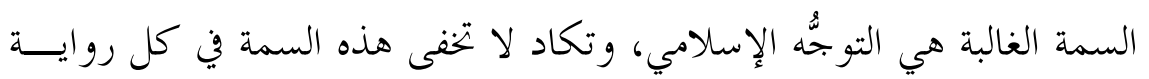

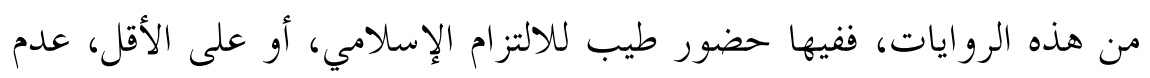

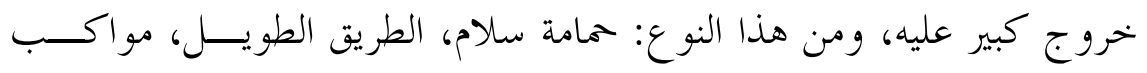
الأحرار، طلائع الفجر" وغيرها كثير من روايات الكيلالي. ج. المستوى المتميز، و في هذا المستوى ترتفع درجة الالتزام الإسلامي. بـ تمح يشير إلى بعض الروايات التي تدخل في هذا المستوى من مثل "عمالقة الشمال،

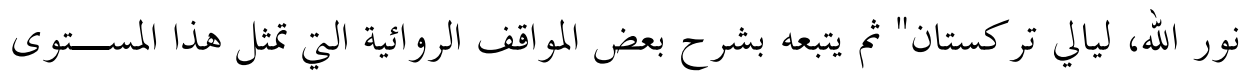

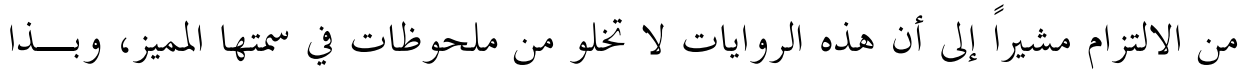

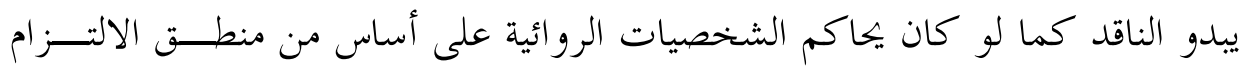
السلوكي والإيماني، وهو خلط وقع فيه الناقد؛ لأن الشخصية الأدبية لها منطقها الخاص

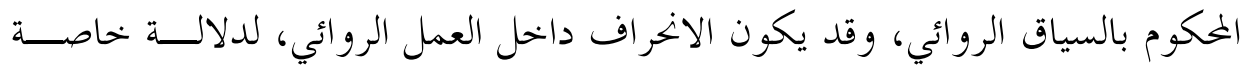

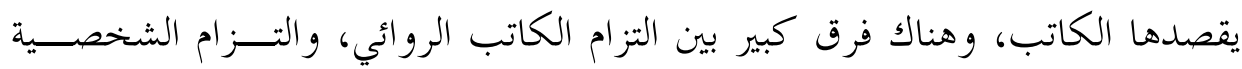

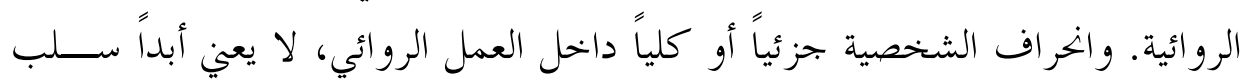

rأ العريني، عبد الله صالح. مستويات الالتزام في روايات بخيب الكيلاني، مجلة الأدب الإسلامي، العدد ا، رابطــة

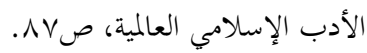

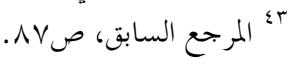


صفة الالتزام من الكاتب ما دام ملتزماً بالرؤية الإسلامية، وغايات السعي البشري التي تتحدد في ضوء تلك الرؤية، وهو ما أطلقنا عليه التزام المنهج لدى النقاد الإسلاميين.

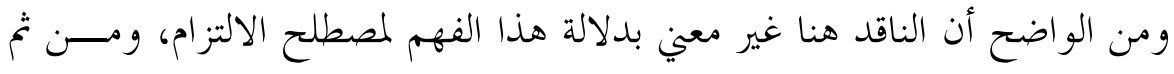

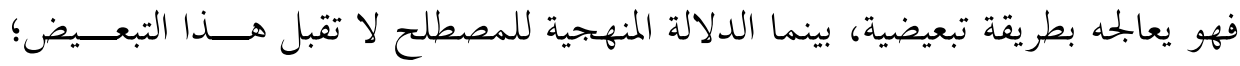
فالأديب يكون ملتزماً أو غير ملتزم، وليس بين الأمرين من وسط، وسطة وإنه لمن الخلط البين أن بحعل ضمن مستويات الالتزام في روايات الكيلاني، مستوى البعد عــن الالتــزام

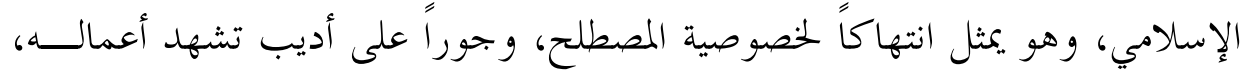
بعمق التزامه، ومنهجيته الإسلامية القائمة على الوعي .كرجعيته الدينية، وواقع النفس، و البحتمع البشري.

\section{هـ الامتداد بالمصطلح من التنظير إلى التطبيق:}

ومن المفهوم المنهجي للالتزام في دائرة الإسلامية ينطلق عماد الدين خليل؛ إذ يشير

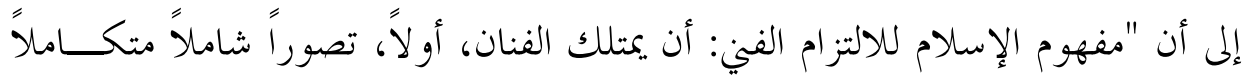

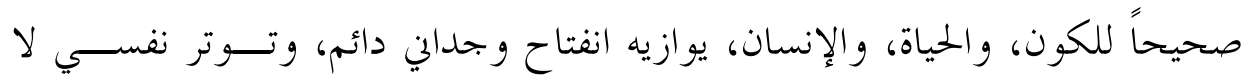

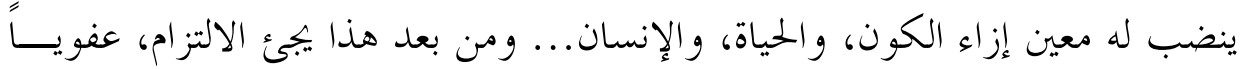

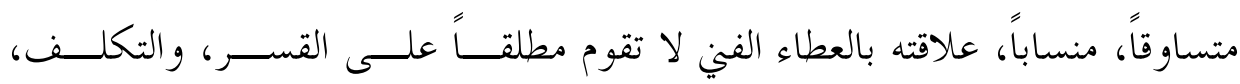

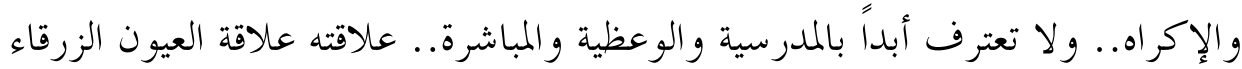
مما يخرج به على حقول الربيع العطشى من ماء فرات.. علاقة التربة الطينية الخصــبة

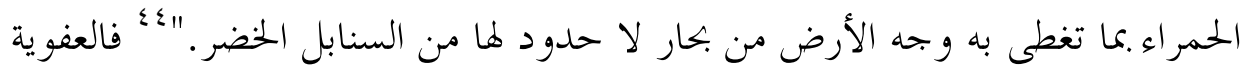
في الالتزام تتحقق من امتلاك التصور الإسلامي إضافة إلى الإحساس الفني بتحاه الكون،

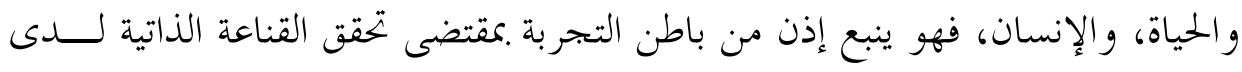

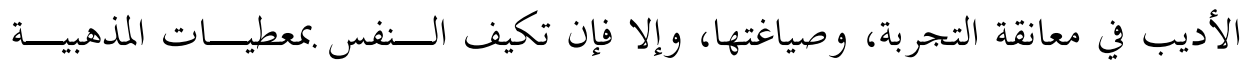

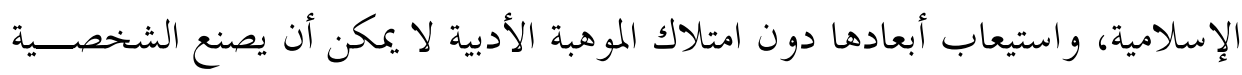
الأدبية. 


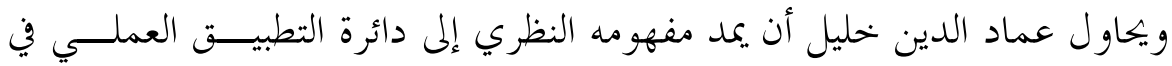

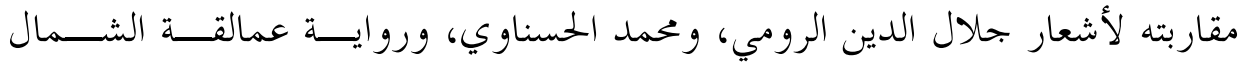

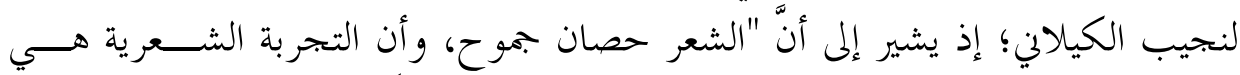

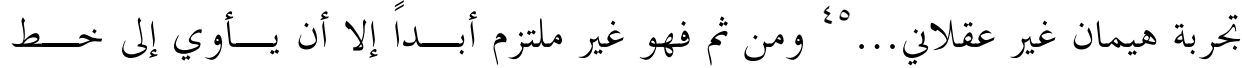

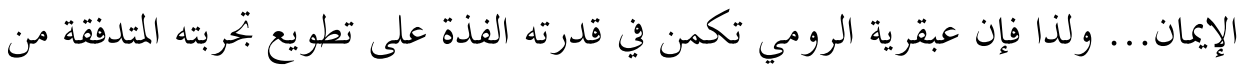

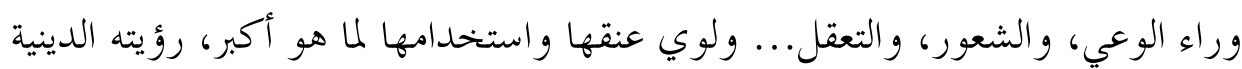

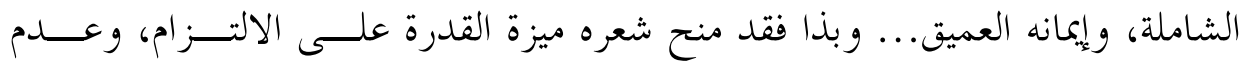

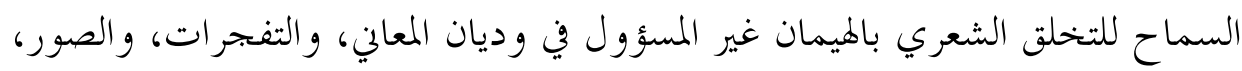

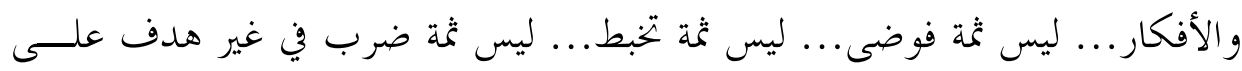

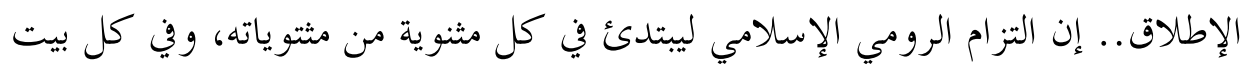

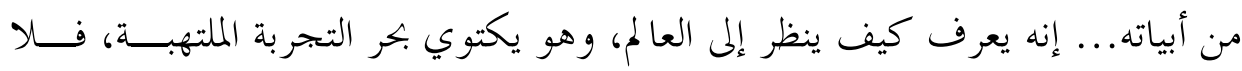

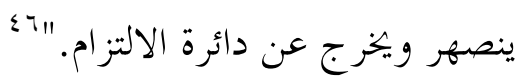

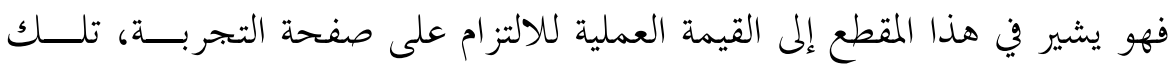

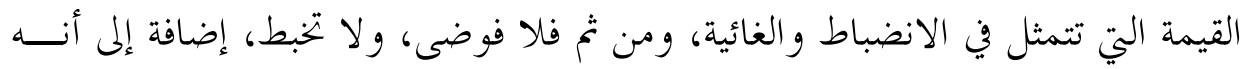

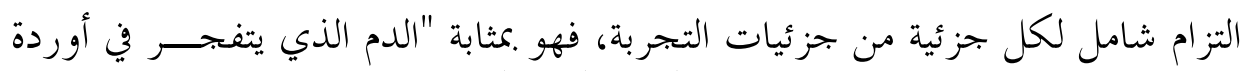

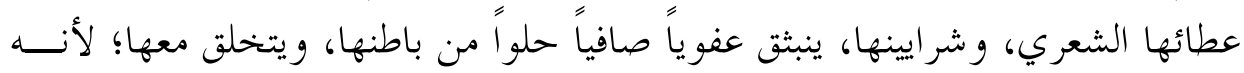

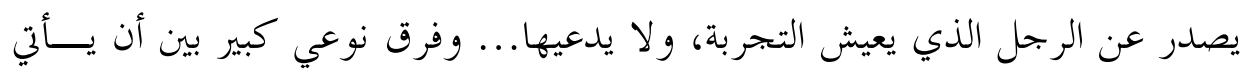

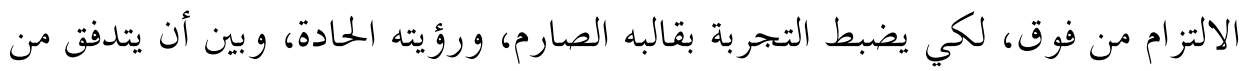

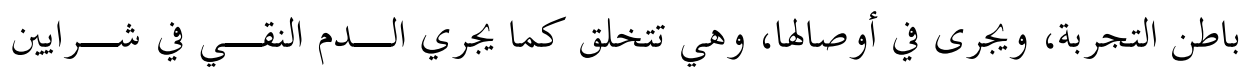

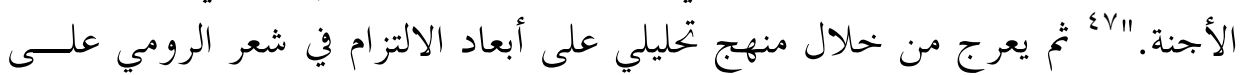
مستوى الشكل و المضمون.

وينتقل في قراعته لشعر الحسناوي إلى بيان القيم العملية للالتزام من جهة أخرى،

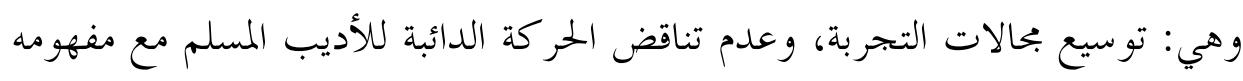
" ؛ تبدو هذه المقولة كما لو كانت صدى لفكرة سارتر عن الشعر والالتزام.

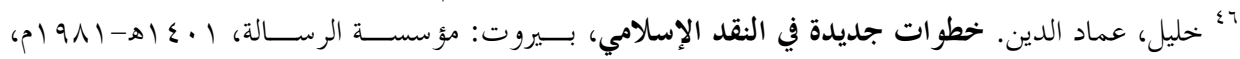

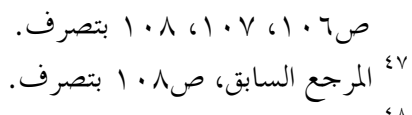

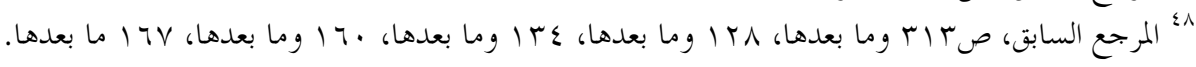




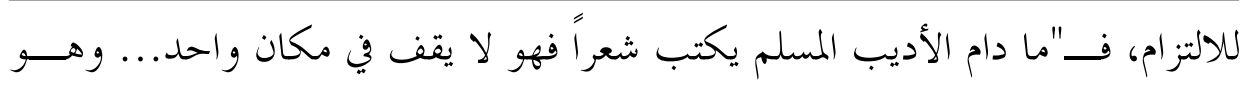

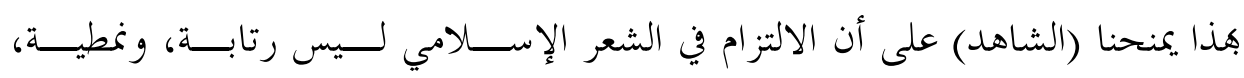

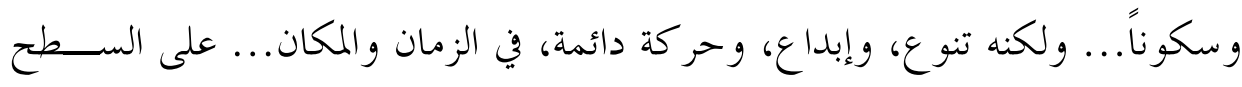

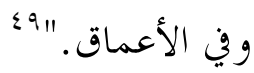

و يلاحظ في مقاربته لرواية عمالقة الشمال أن الأديب الروائي بنجيــبـ الكـــيلاني استطاع توزيع لمساته الإسلامية، ورؤاه الإيمانية على جميع مساحات الرواية دون سرد

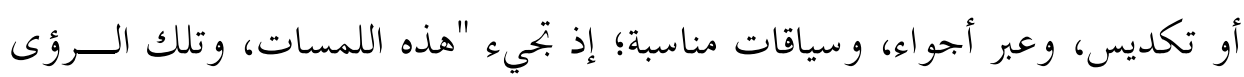

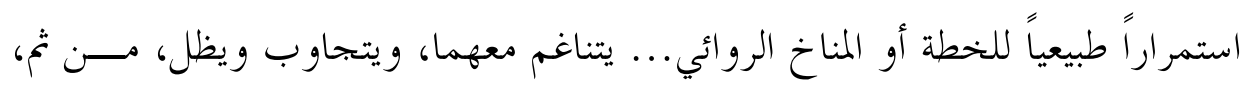

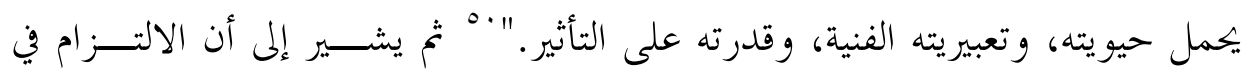
الرواية يتحرك على مستويين: مستوى العمل الفين بكامله بصــفته روايـــة إســلامية

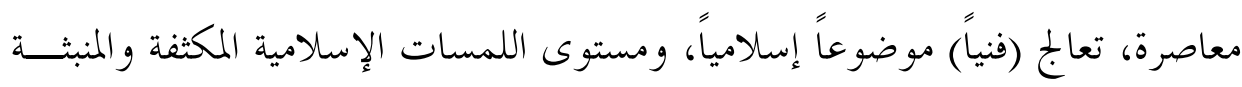

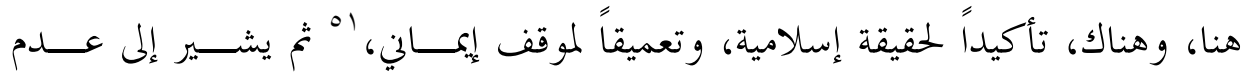

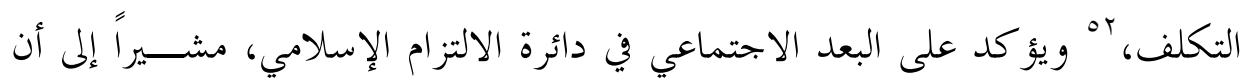
الكيلالي وضع في روايته بعض الخطوط، و اللمسات عن المسألة الاجتماعية التي تؤرق

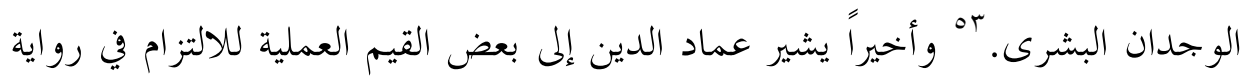

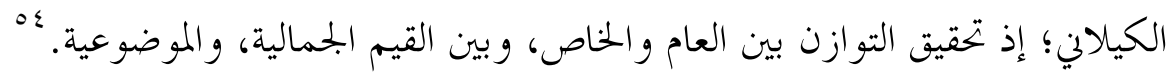
وعلى هذا فإن عماد الدين قد امتد بالمصطلح (الالتزام) من دائرة الممارسة النظرية إلى دائرة التطبيق النقدي؛ إذ أشار إلى بعض القيم العملية للالتزام، واتخذ من المصطلح

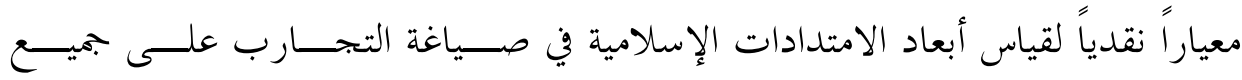

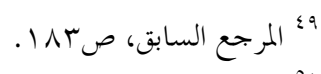

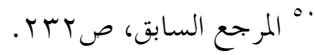

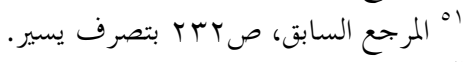

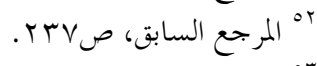

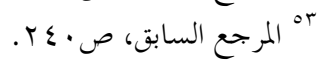

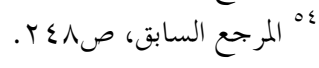


مستويات البناء الأدبي بجناحيه: الفكري، والجمالي، ومن ثم فقد وضع يده على أبعـاد الالتزام في كل جزئية من جزئيات العمل الفني.

وضمن كشفه عن أبعاد الإسلامية في الرواية يقول: "ولا ينسى الكيالي أن يضع

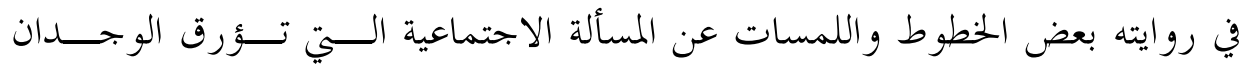
البشرى، و التي يحسب لها الموقف الإسلامي ألف حساب." له وذلك على الرغم من أنه لم يشر صراحة في المفهوم النظري للالتزام إلى البعد الاجتماعي؛ لأنه لا يوجد فاصــل

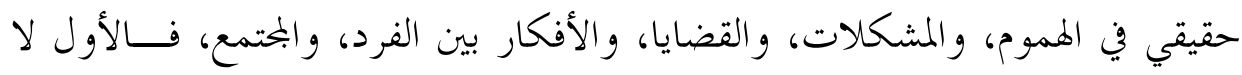

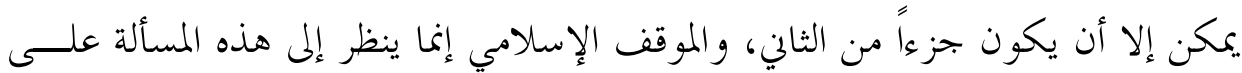

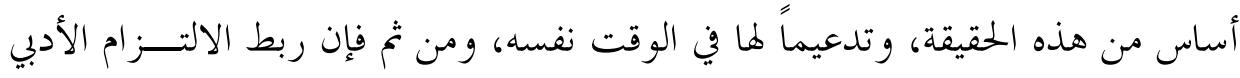

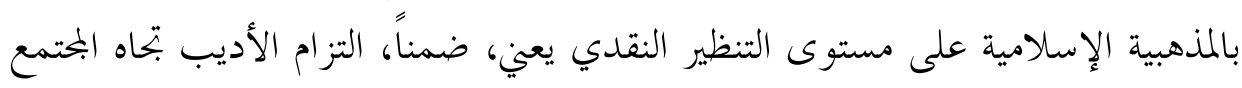

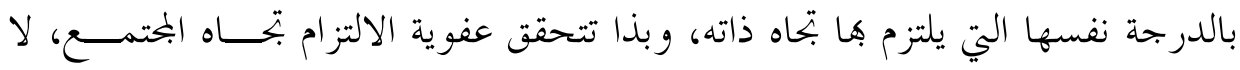

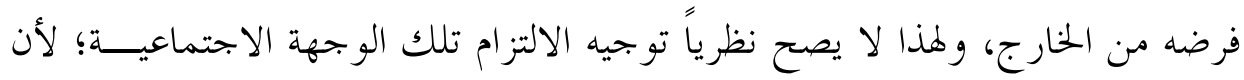

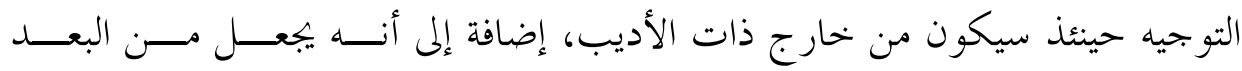
الاجتماعي في الالتزام، وهو فرع فيه، جذراً يزاحم به الجذر الأصلي في الالتزام، وهو

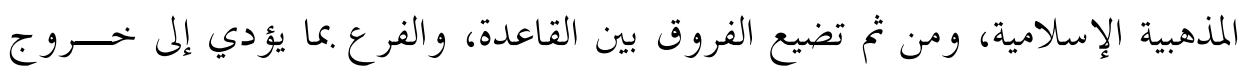

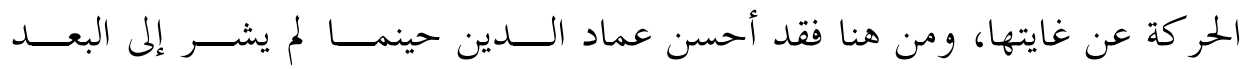
الاجتماعي في الالتزام الأدبي على المستوى النظري، و لا بأس بالتأشير النقدي في دائرة

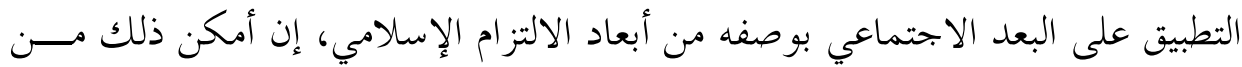

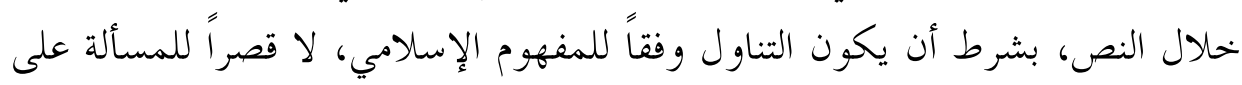

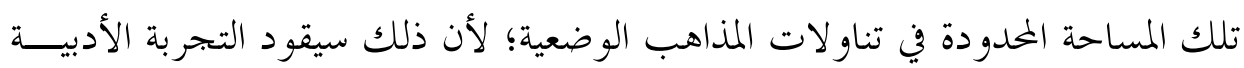

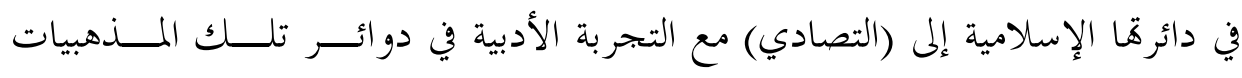
الضيقة، إضافة إلى أنه يقود إلى تشابه الإسلامية في هذا الجانب مع الماندهان المهبيات الوضعية، على الرغم من وضوح تباينها عن تلك المذهبيات. 
مرة أخرى يشير عماد الدين خليل إلى بعض القيم العملية للالتزام، له فهو الخـــيط

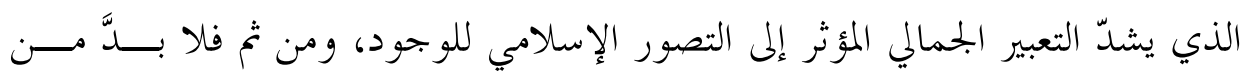

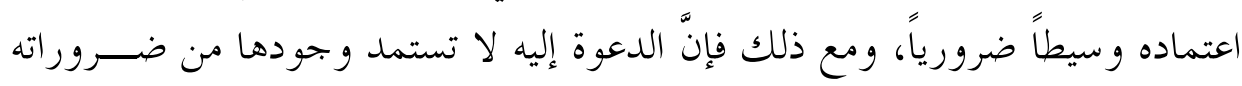

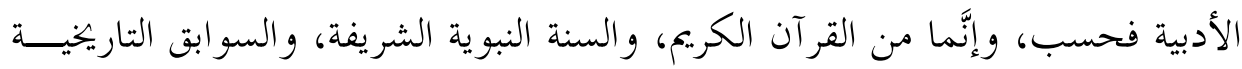

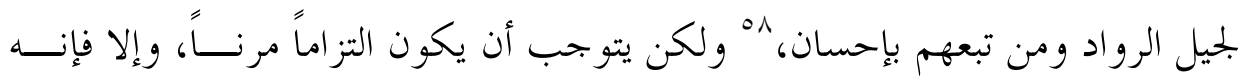

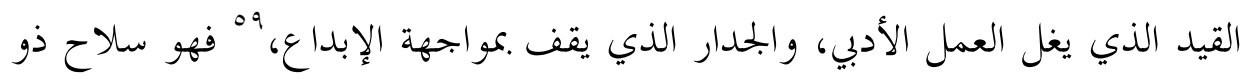

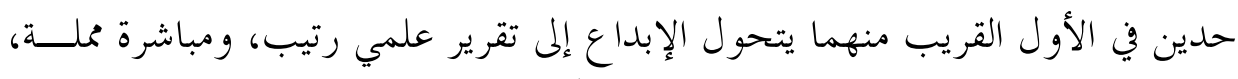

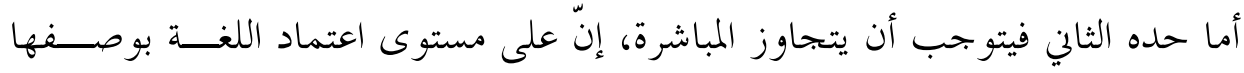

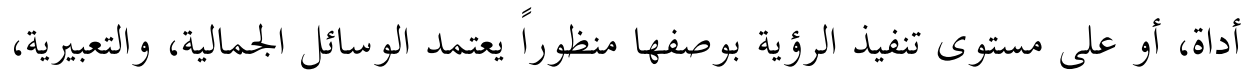

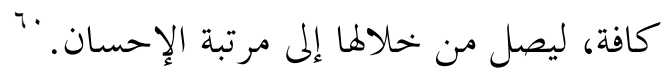

وعلى هذا فإن عماد الدين خليل يؤكد المفهوم المنهجي للالتزام في الإســلامية، ذلك المفهوم الذي تصبح التجربة في إطاره تمخضاً تلقائياً عن التمازج الحيوي في باطن الذات المبدعة بين المقدرة الإبداعية التي تمتلك مقومات الإبداع الأدبي كافة، والتصور النابع من المذهبية الإسلامية الشاملة، ذلك التصور الضارب بجذوره في عمــق الــيقين

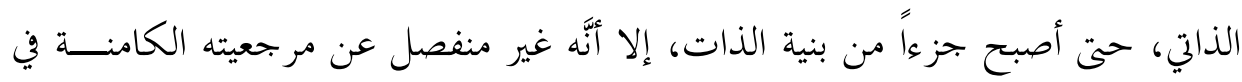

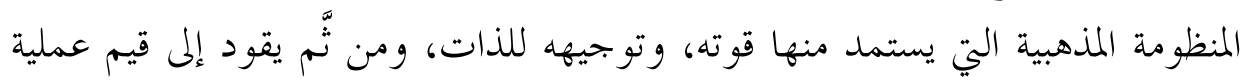
في صياغة التجربة.

- مقال في العدل الاجتماعي، بيروت: مؤسسة الرسالة.

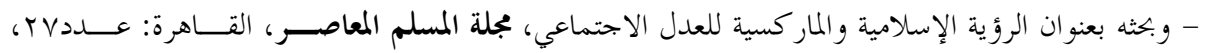

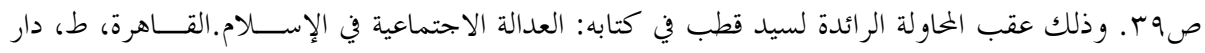
الشروق.

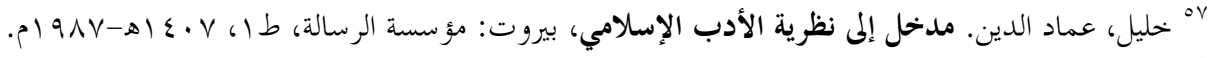

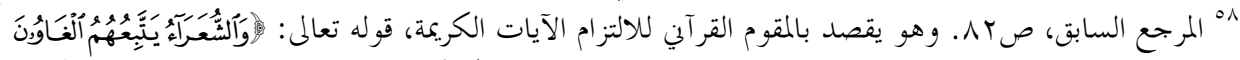

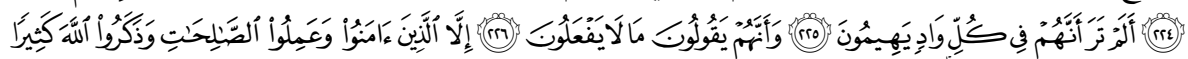

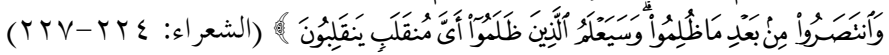

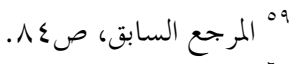

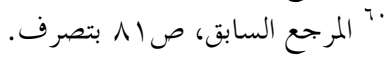


ويستخدمه مصطفي عليان "آ في دراسته النظرية، .كعناه المنهجي؛ أي الالتــزام في "الأهداف، والأخلاق، والأشواق"rآ وكافة تمخضات التجربة وسائر العناصر المكونة لما، بالتصور الإسلامي، غير أنه يستخدمه من الناحية التطبيقية في ابتحاهات متعــددة، حيث يقيده بالمحتوى الفكري، وما يتعلق به من تصورات وقيم. "آّأي إنه التزام تجاه المضمون، كما يطلقه نحو التوجه الدعوى في الأدب، گج أو .معنى التمسك بعنصر الوعي

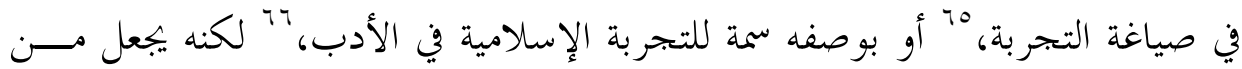

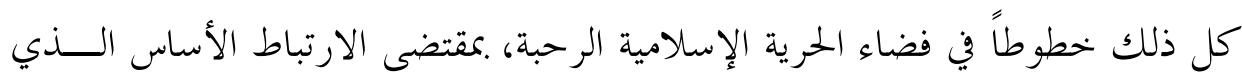

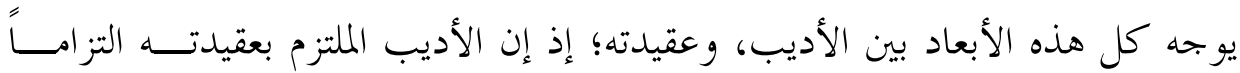
فطرياً، يبعل الحق، و النقاء، والسمو، و النظافة، والخير، قيماً عفوية في سلو كه، لا قيوداً جبرية، لآ ومن ثم فهي لا تتعارض مع الحرية، ولا مع الحدود، و القوانين الإسلامية التي تحكم حر كة البحتمع، والحياة الإسلامية، فكأن عليان إذن يستخدم المصطلح في البحسـال

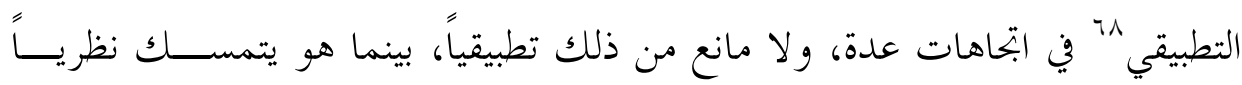
بالمفهوم المنهجي للالتزام، أي أن يجئ التناول الأدبي، أياً كان بحاله، متسقاً مع التصور

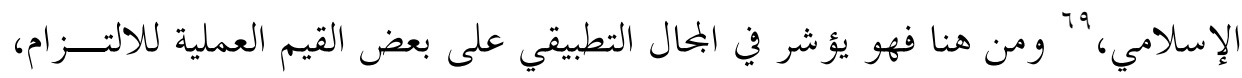
" ناقد إسلامي صدر له حتى الآن كتابان في هذا المحال: مقدمة لدراسة الأدب الإسلامي، ونخو منهج إسلامي في رواية الشعر ونقده. إضافة إلى بعض المقالات كنات في بحلة الأل الأمة القطرية.

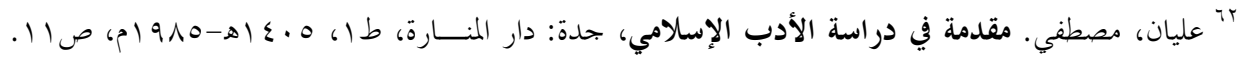

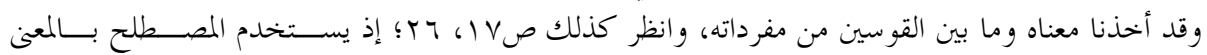
المذكور، ولكن من خلال تعبيرات أخرى.

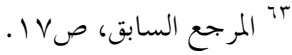

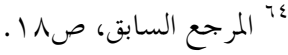

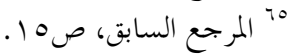

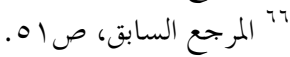

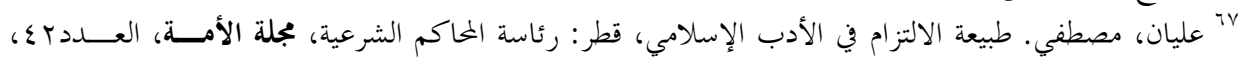

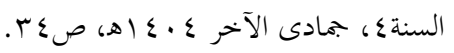

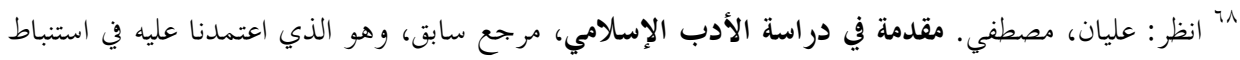
هذه الاستخدامات للالتز ام. 797 عليان، مصطفي. طبيعة الالتزام في الأدب الإسلامي، مرجع سابق، صـ ؟. 


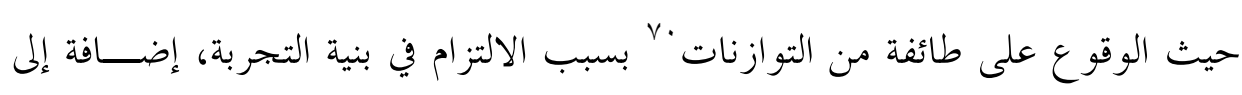

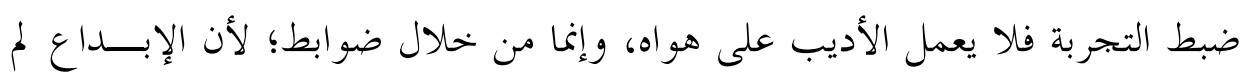
يكن في يوم من الأيام عملاً بحانياً.

ثالثاً: تأثير ات و افدة في سياق التأصيل

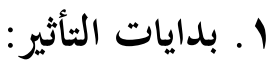

يقدم الكيلالي توضيحات ذات قيمة وأهمية في المعالجة الإسامية للمصطلح، مــن مثل ترتيب الالتزام على المسؤولية، وعمومها لجميع الأفراد، وشثمولها لحركة الإنســان المسلم على جميع المستويات، وربطه للالتزام بالمنهج الإسلامي، وإشارته إلى شمول هذا

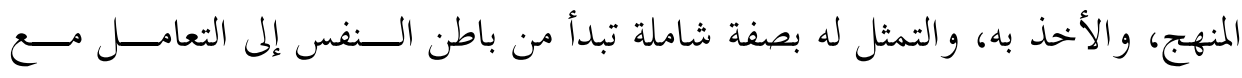

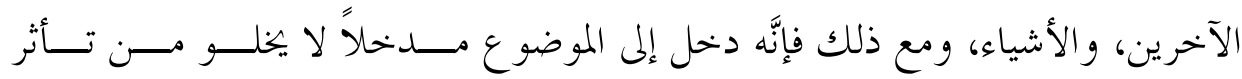
بالمضمون الغربي للمصطلح، فهو يضع بدايةً الالتزام مقابل الحرية، ثم يشير إلى التوافت

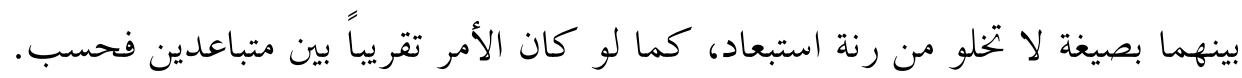
ثم إنه حينما ربط المصطلح (الالتزام) بالمضمون الإسلامي (المنهج) لم يشأ أن يجعل هذا

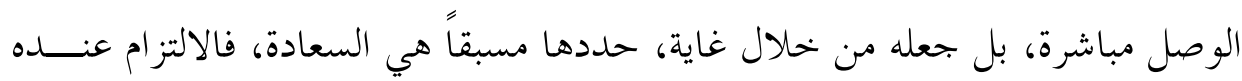

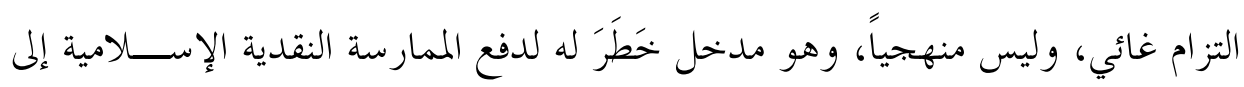

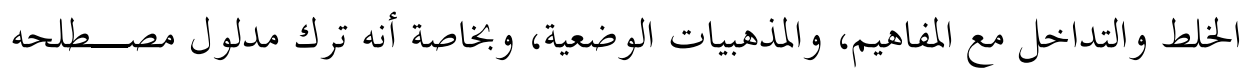
الغائي (السعادة) بإطلاق دون كشف أبعاده الإسلامية، إلا إشارة عــابرة إلى ربــــ

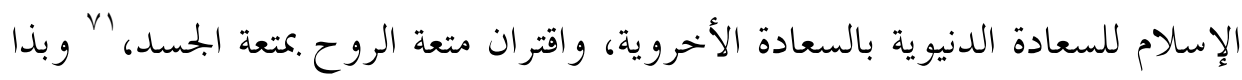
يمكن توجيه الأدب الإسلامي وجهات مادية، أو روحية غير إسلامية، تنطوي تحــت 
هذا المفهوم للسعادة، أو على الأقل يتشابه مع هذه الابتاهات، و من ثم ينحرف عــن منهجه، و وغايته معاً. كما أن المفهوم الغائي للالتزام ما زال مسيطراً عليه، ومتلبساً به، بالوهو ما يؤخذ

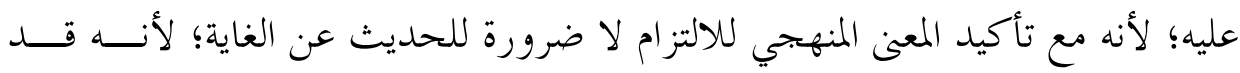
يؤدى إلى خطأ في الفهم، ما قد يضع حدوداً أمام حركة الأديب. عَّل لذا فمن الأفضل التركيز على الالتز ام بحاه المذهبية الإسلامية، و الغايات بعد ذلك تأتى ثمرة طبيعية هـــــا

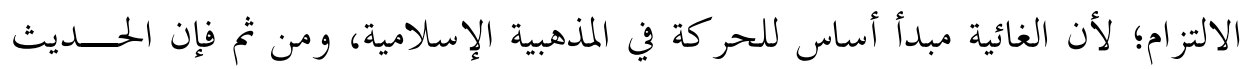
عنها هنا، على ما له من سلبيات في دائرة التداول النقدي، هو تكرار غير مسوّغ. وعلى الرغم من استيعاب الكيلاني للمفهوم الإسلامي، وتطبيقاتـــهـ العمليــة في

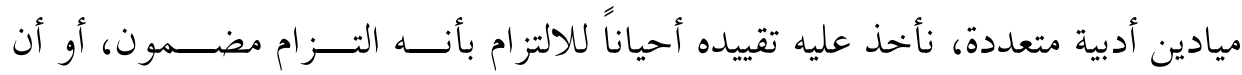

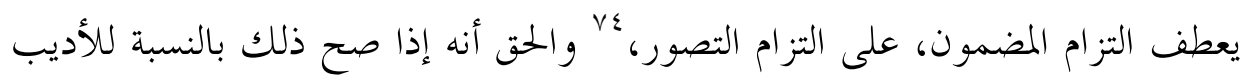

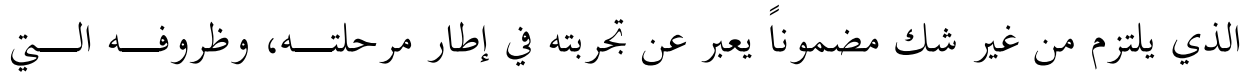

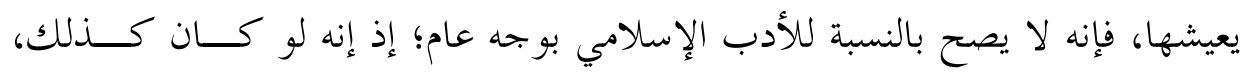
لسقط في دائرة الجمود، و التقليد، كما حدث للأدب في ظــل الواقعيـــة الاشــتر اكية بسبب توقف حركة المضمون في صياغة التجارب، لذا فهو لا يلتزم مضـــموناً ثابتــاً،

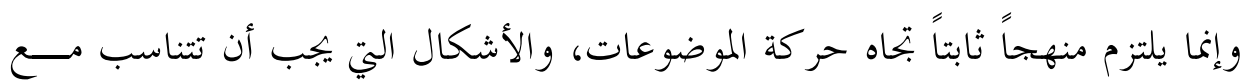

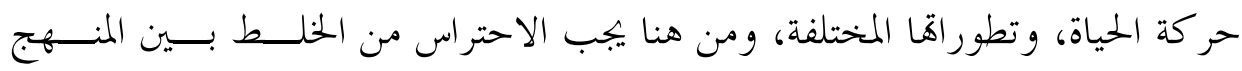
و المضمون في طرح مفهوم الالتزام في دائرة الإسلامية.

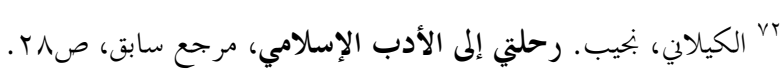

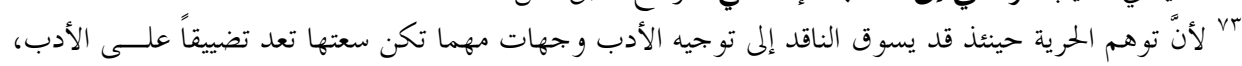
مثل حصر حر كته في دائرة الاهتمامات الاجتماعية وما أشبه ذلك. 


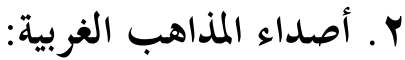

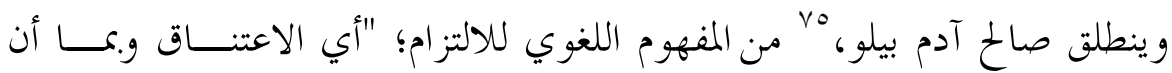

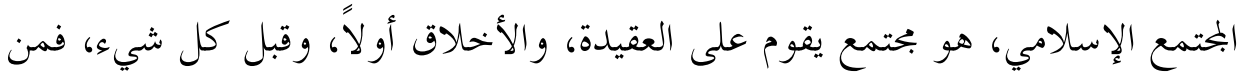

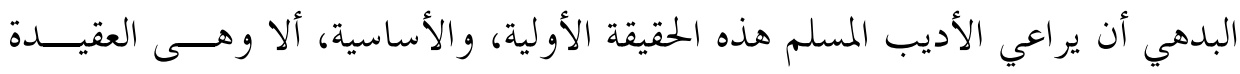

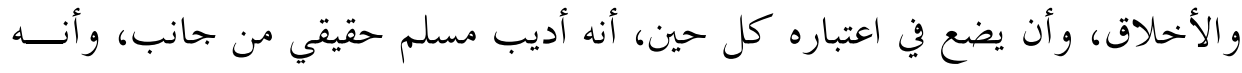

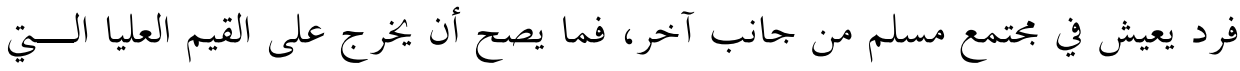

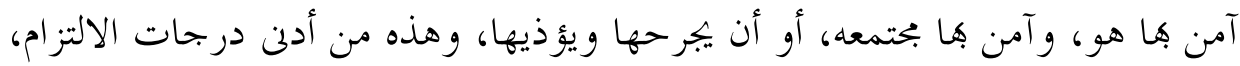

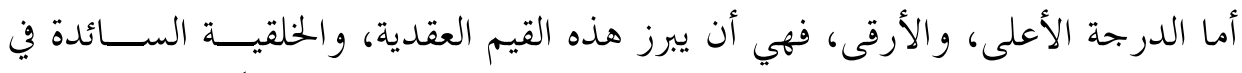

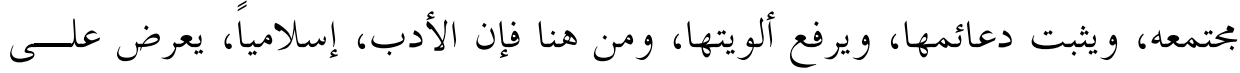

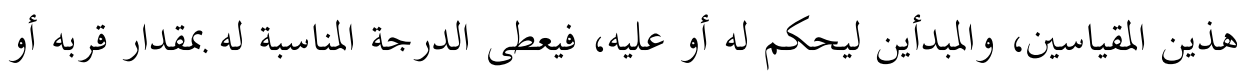

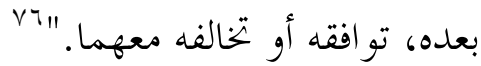

إذن فهو ينطلق في تحديده لمعنى الالتزام من المعنى اللغوي إلى الغايات الوظيفية التي

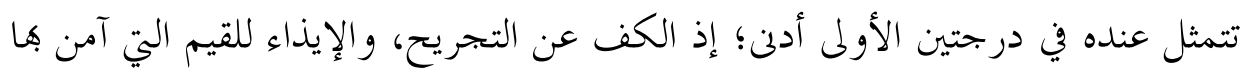

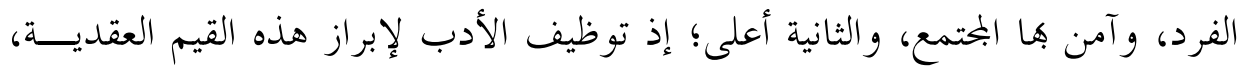

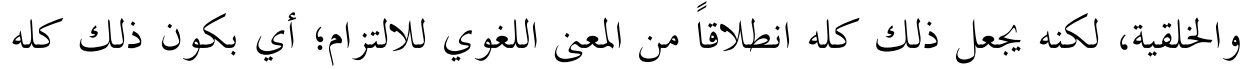

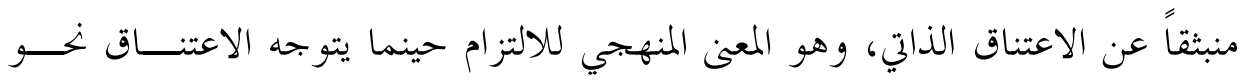

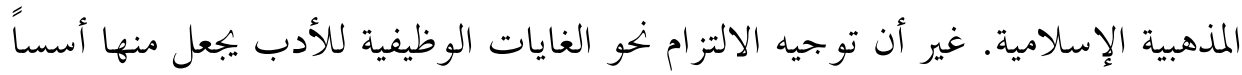

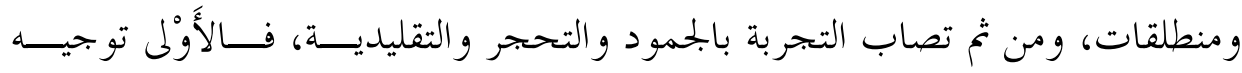

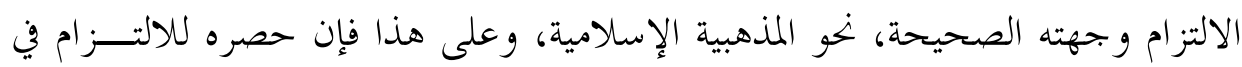

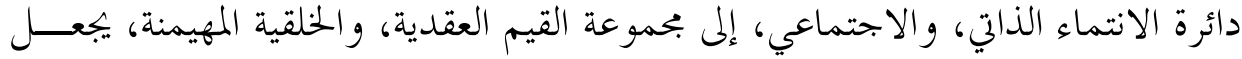

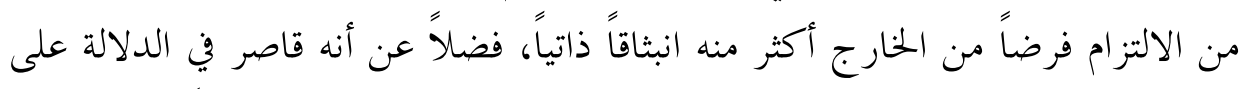

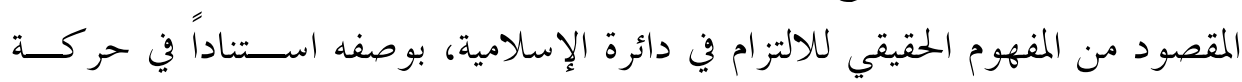

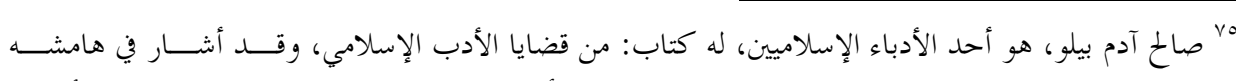

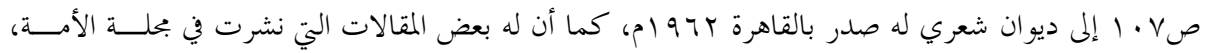
وبلة الأدب الإسلامي.

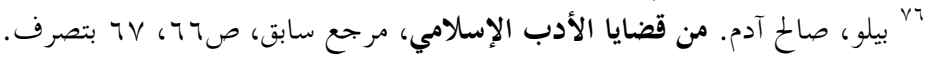


الصياغة الأدبية إلى منظومة مفاهيم المذهبية الإسلامية المتكاملة الــتي يتشـــكل علــى

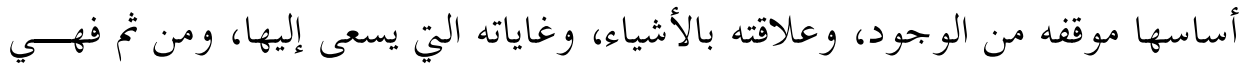
تشكل بالنسبة له قاعدة مرجعية، ثم إن التعبير عن حقائق العقيدة بالقيم العقدية، قد لا لا

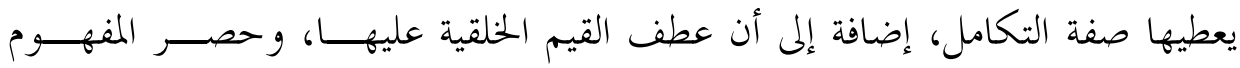
الالتزامي في بحموعة القيم العقدية، والخلقية، يفصل بين القاعدة، والفروع التي انبثقت عنها، وبذا يتضخم الفرع ليصبح أصلاً، الأمر الذي لا يخلو من تضييق وقسر وإكراه، ئهين

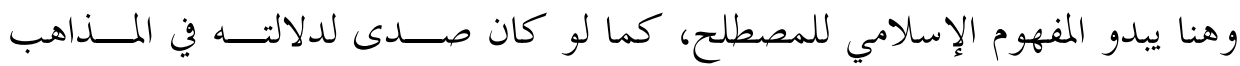

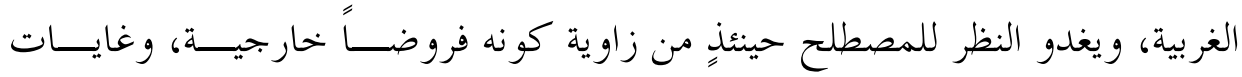
وظيفية.

ومما لا شك فيه أنَّ القيم الخلقية في الأدب تتحقق .مقتضى الارتباط المذهبي، فهي

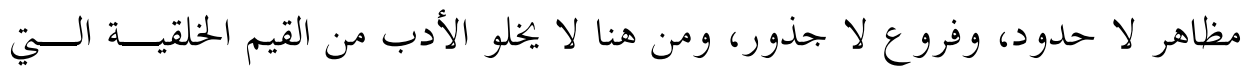
تتلون بطبيعة الارتباط المذهبي المحرك للتجربة، لذا فإن تحديد الالتزام بالقيم الخلقية غير لهن

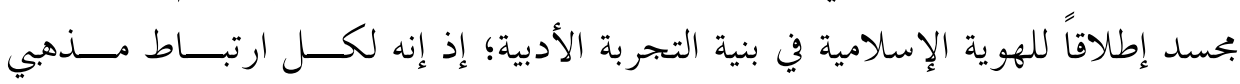
أخلاقياته التي تتمخض عنه.

وقد بنى (بيلو) فكرته في التفريق بين درجتي الالتزام، على النحو المشار إليه، على

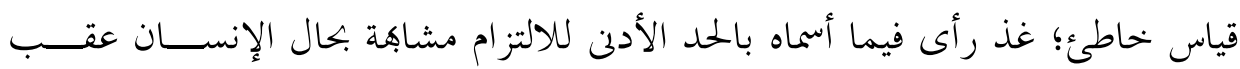
دخوله في الإسلام مباشرة، فهو يكف عن السوء، ولكن لا يكتمل إسلامه إلا بعمـلـ لإسل

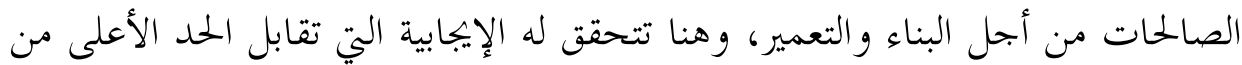

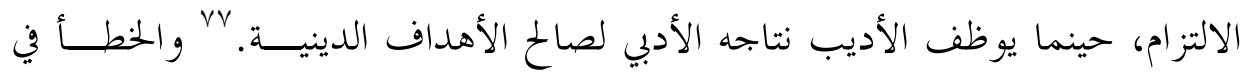

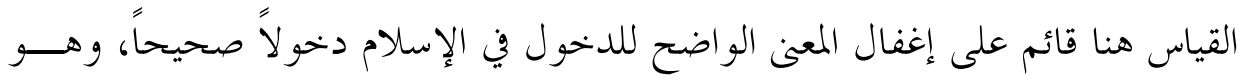

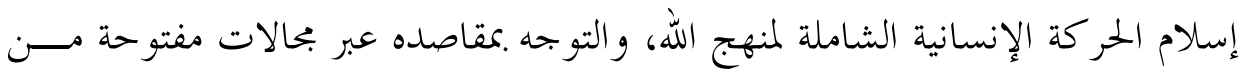

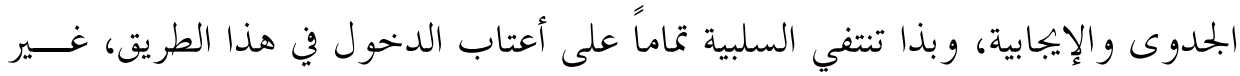

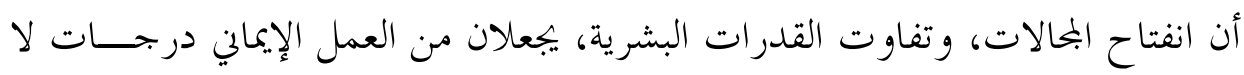
PV بيلو، صالح آدم. الالتزام في الأدب الإسلامي، مجلة الأدب الإسلامي، رابطة الأدب الإسلامي العالمية، عددץ، 


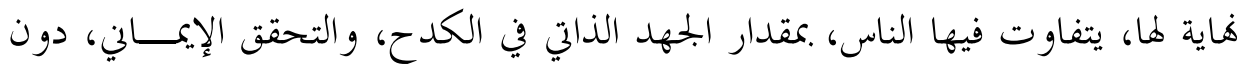

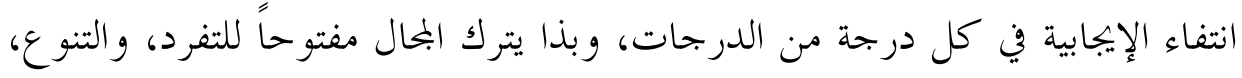

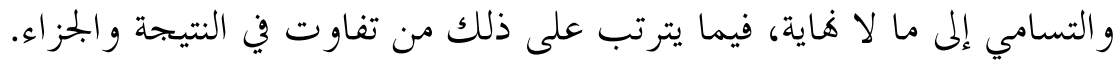

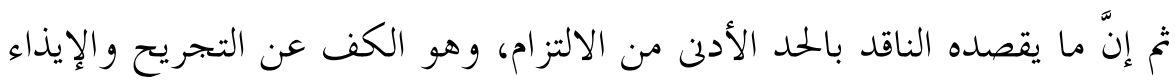

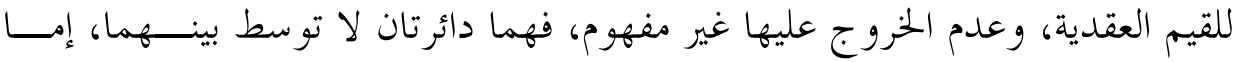

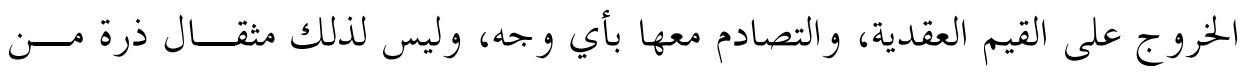

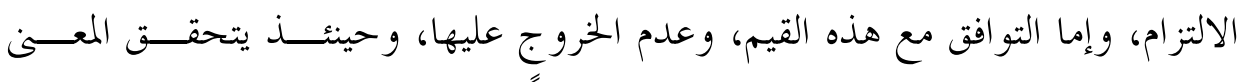

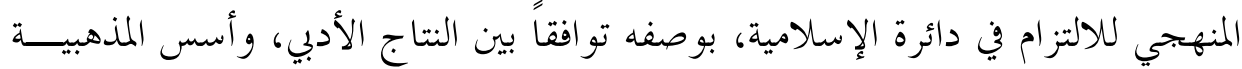

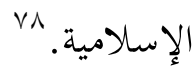

وليس بعد ذلك من متزلة للعلو في الالتزام، وما أسماه الناقد بالدرجة الأعلــى في

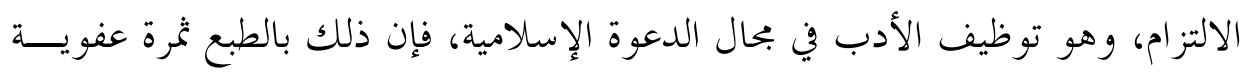

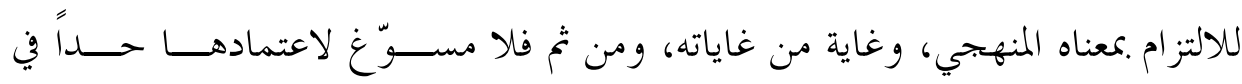

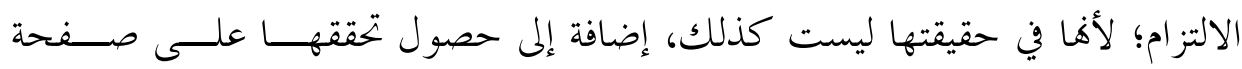

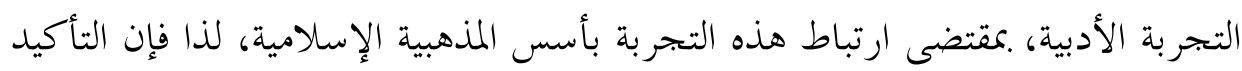

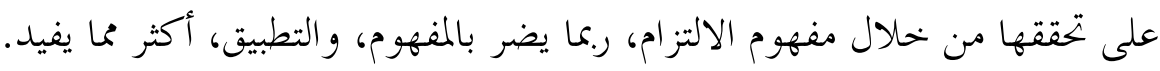

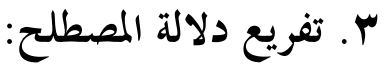

تمتد هذه الأصداء، لدلالة المصطلح في المذاهب الغربية، في أجواء النقد الإسلامي؛

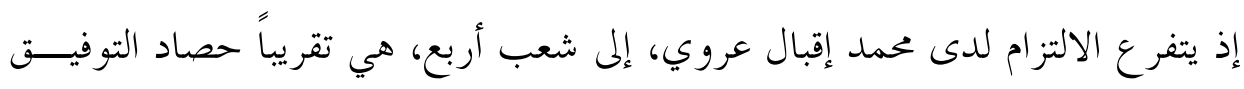

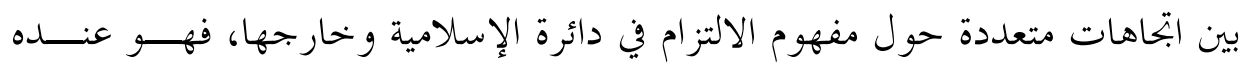

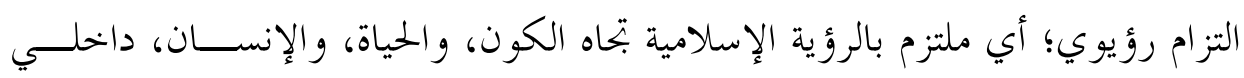

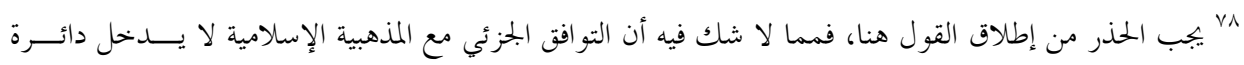

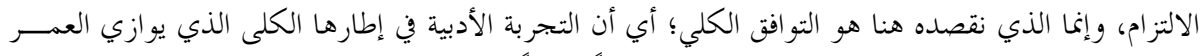

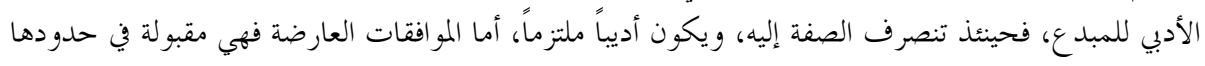


ملتزم بالاهتمامات الذاتية، أدبي أي ملتزم بتحاه القيم الأدبيـــة، خهـارجي؛ أي ملتـــزم

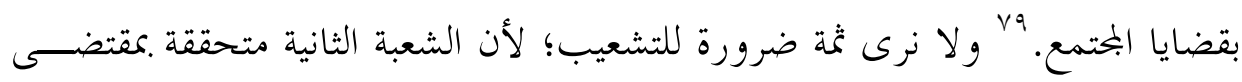
حتمية الذاتية في تشكيل التجارب الأدبية، بل إن الذاتية هي جوهر التجربة الأدبيــة، و الموضوعية فيها لا تتجاوز الشكل بحال من الأحوال، ثم إن القيم الجمالية، والقضـــايا الاجتماعية، كلتيهما تتجسدان في بنية التجربة، وتتحققان مكقتضى خضـــوع الــــص الأدبي للقو اعد الجمالية في الأدب، و التعالق الضروري بين الفرد و البحتمع، على أســـاس

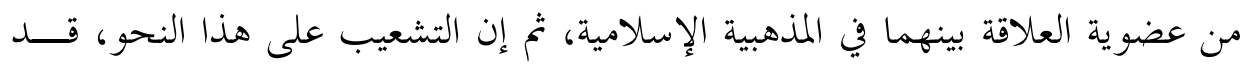
يجعل، على المدى الطويل، هذه القيم الجمالية والاجتماعية في ابحاه، و الأسس المذهبيـــة

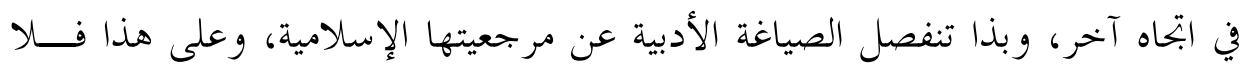

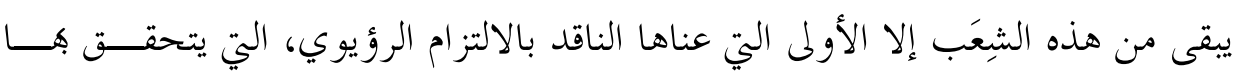
المفهوم المنهجي للالتزام.

ويتفق معه في هذا التشعيب كثير من النقاد على اختلافهم في الناحية الكميـــة؛ إذ يراه الشنطي •^ في شعبتين، تتجه الأولى منهما بتحاه المذهبية الإسلامية، و تنحصر الثانية

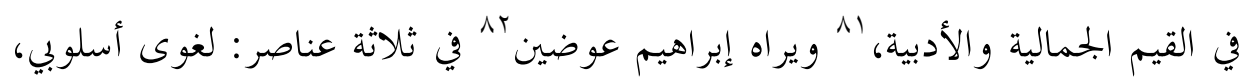

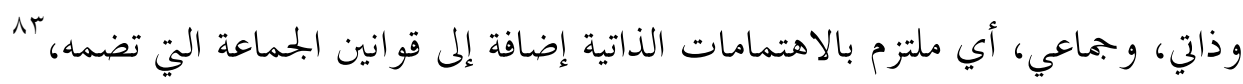
وهو يربط ذلك كله بالاستجابة الفطرية العفوية للمذهبية الإسلامية، فهو طاعة لكـــل

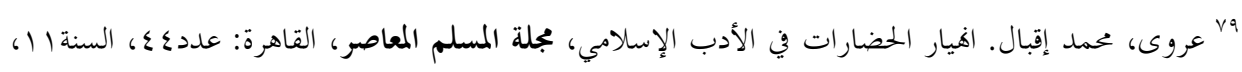

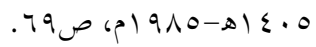

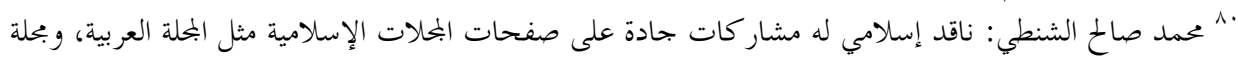

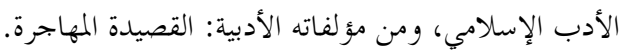

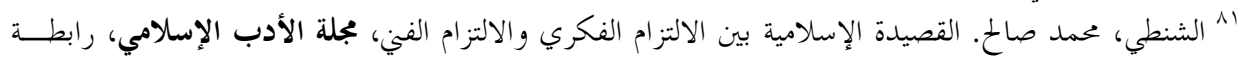

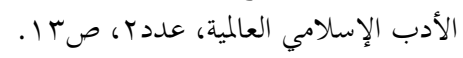

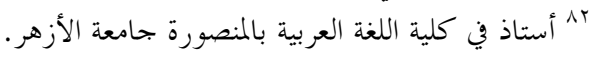

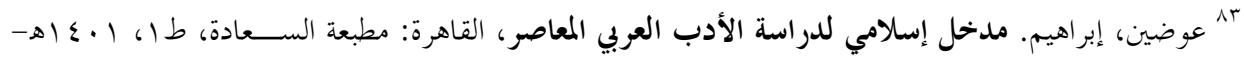

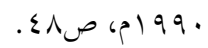




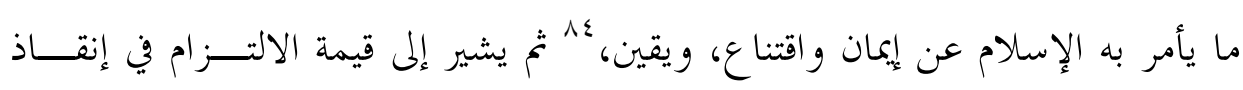
الأديب، و التجربة معاً من شرك الازدو الإدية.

\section{رابعاً: تلبيس المصطلح و اختلاط المفاهيم}

ومن هذا المفهوم المنهجي نفسه ينطلق محمد حسن بـــيغش، آد إلا أنسـه يعـبر تعبيرات، ويضيف إضافات فيها كثير من الخلط، و التلبيس، والإرباك، فهو ابتداء يشير

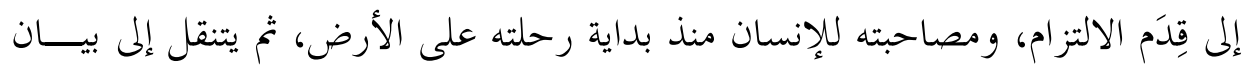
صفة الأديب المسلم الذي يرى أن هويته لا تتحدد إلا من خلال هذه الصفة (المسلم)، وأنه لا يدخل في إطار الأدب الإسلامي إلا من هذا المدخل؛ لأن صفة الأديب يشترك

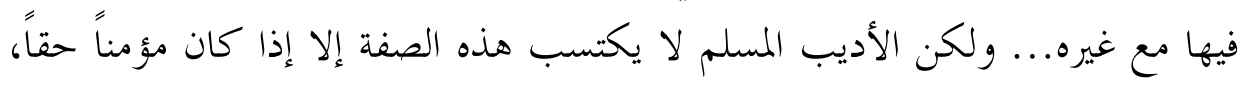

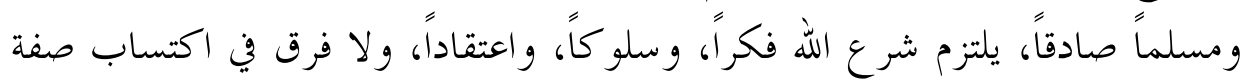

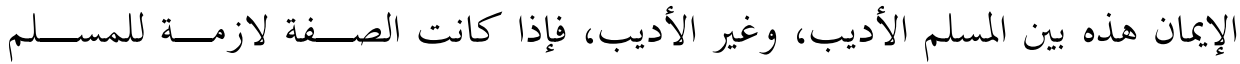

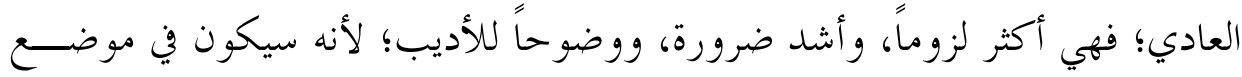
التأثير والتوجيه و الريادة، ومن ثم فلا يقبل إطلاق الصفة على رجلى رجل لم يلتزم بالإســاملام في سلو كه العملي، ونشاطه الحيوي الشامل.

و بذا يصل بريغش إلى مفهومه المنهجي، فما دام المسلم مســـؤو لاً عــن مطابقــــة

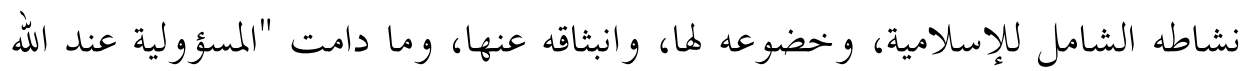

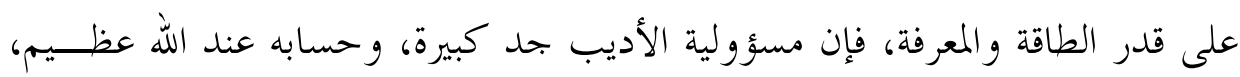

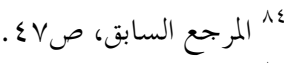

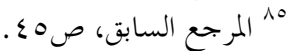

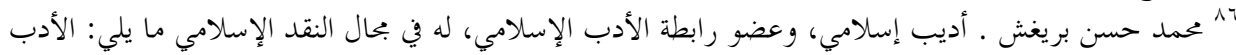

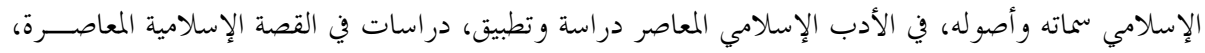

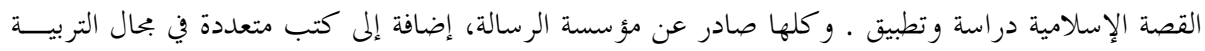

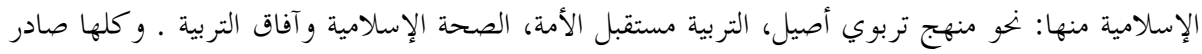
عن مؤسسة الرسالة

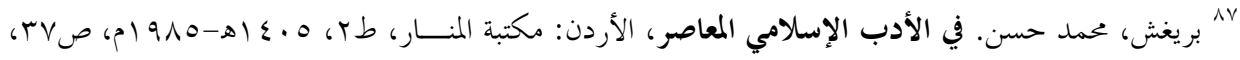




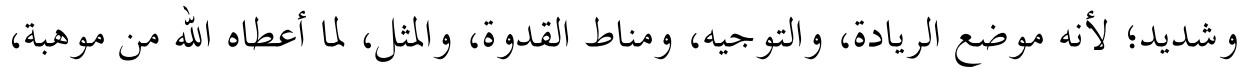

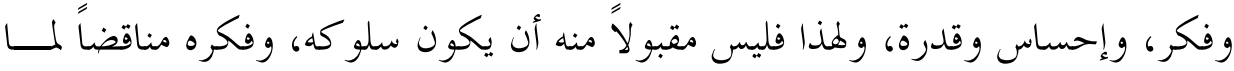

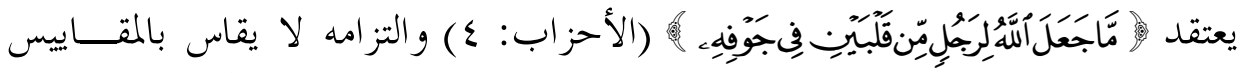

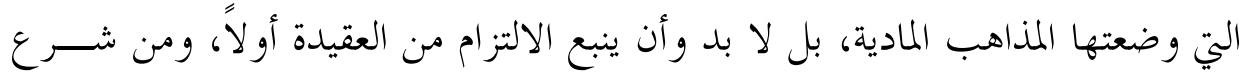

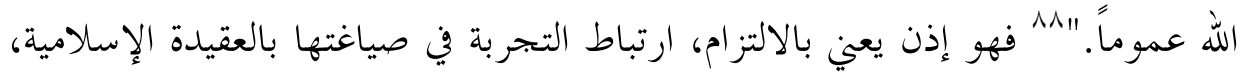

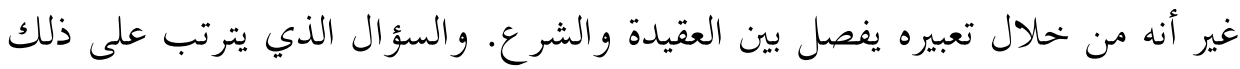
هو هل تتو افق التجربة في صياغتها مع العقيدة ثم تصطدم بالشرع؟ ولما كان ذلك يقع

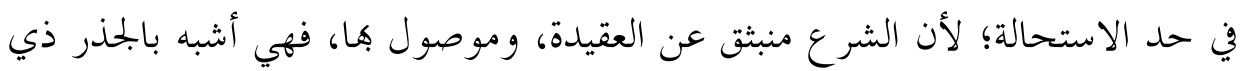
الامتدادات المختلفة لتغطية أبعاد الحياة كافة؛ إذ يأخذ كل جانب منها ما يستظل به،

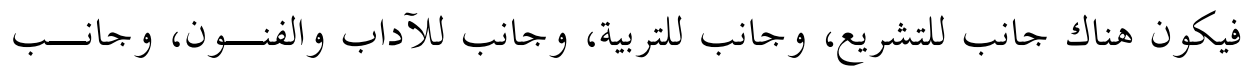

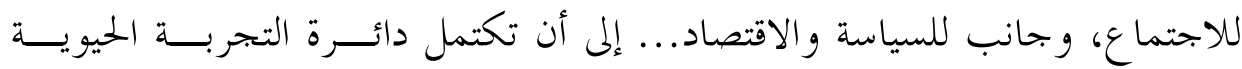
للإنسان، فتكون حياته في جزئياها، وعمو مها في إطار إسلامي، وتكون كل الجوانب

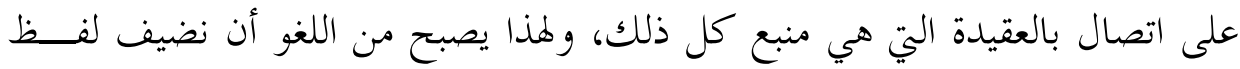

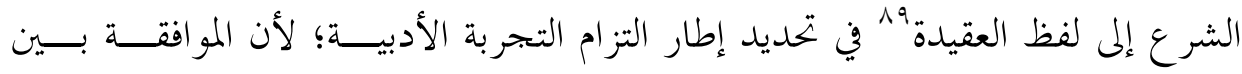
التجربة، والحدود الشرعية حاصلة بمقتضى مو افقة التجربة للعقيدة الإسلامية.

وهو لا يكتفي بكو افقة التجربة للعقيدة، والشرع، و إنما يضيف موافقة أخرى تتمثل

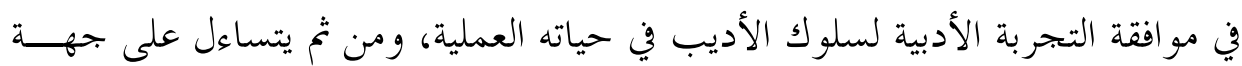

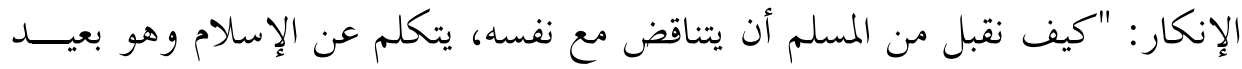

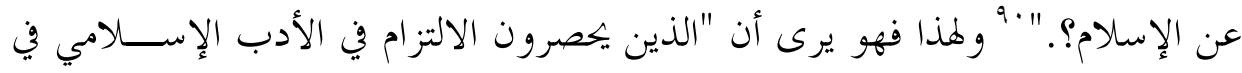

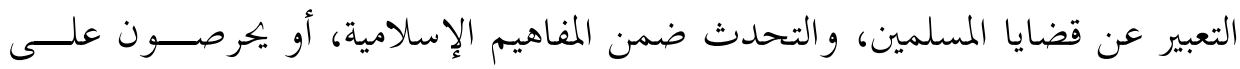

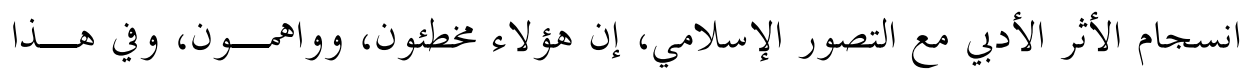

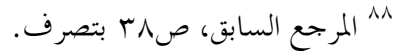

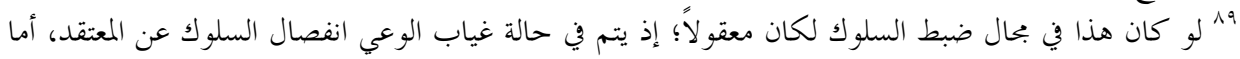

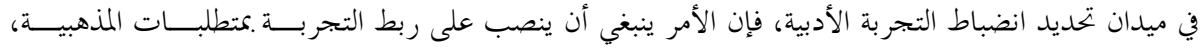

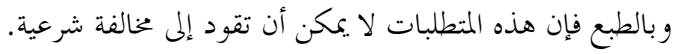

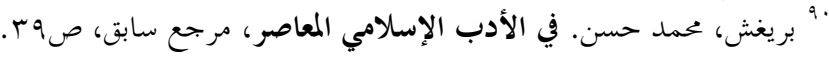




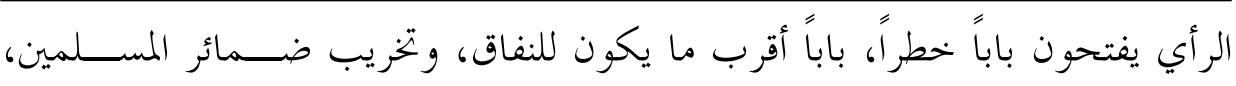

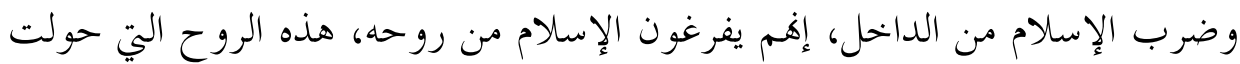

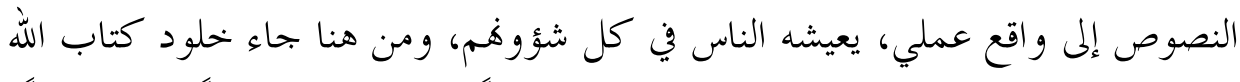

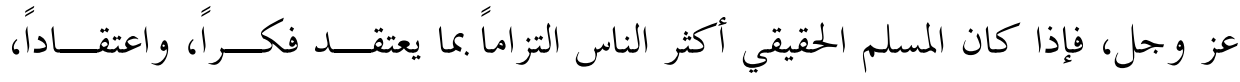

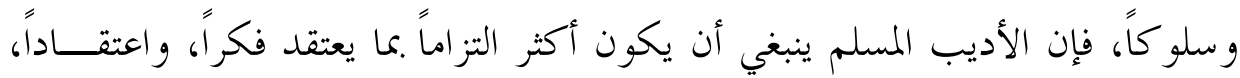

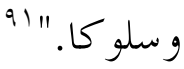

وعلى الرغم من أن ذلك صحيح في جوهره في المحال التربوي، إلا أنسـه يخــــــاج

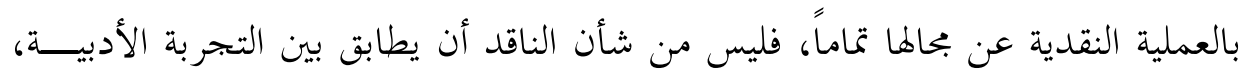

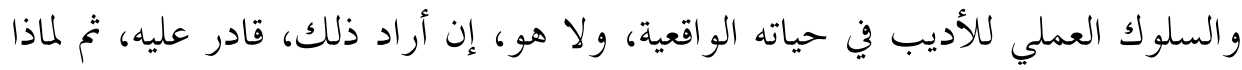

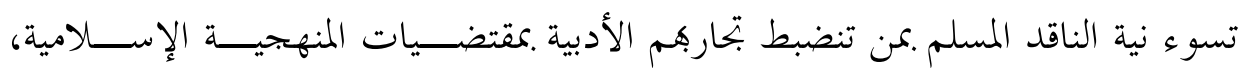

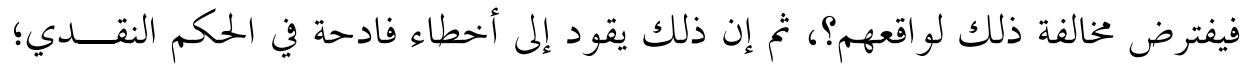

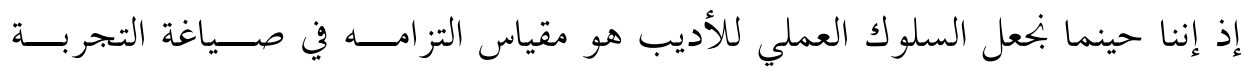

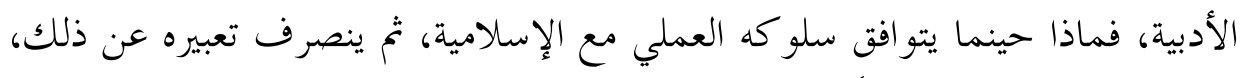

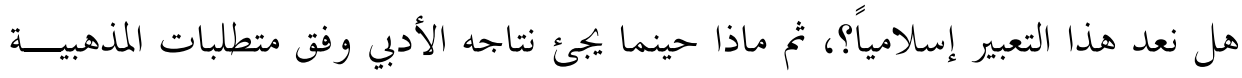

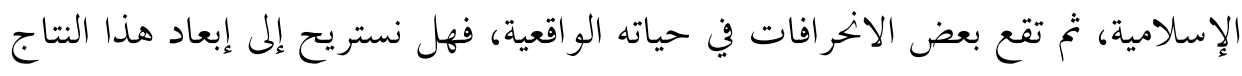

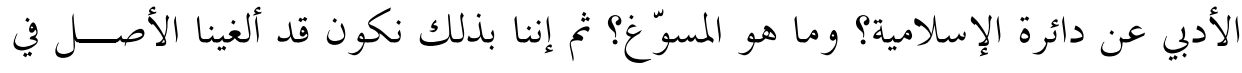

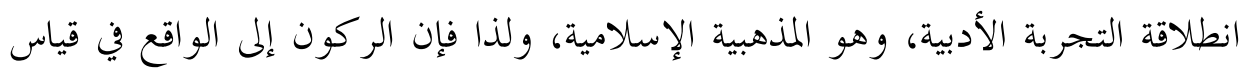

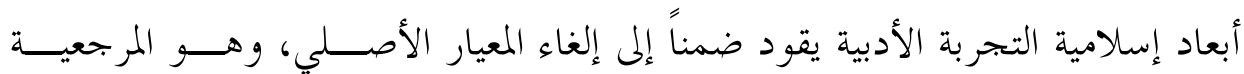

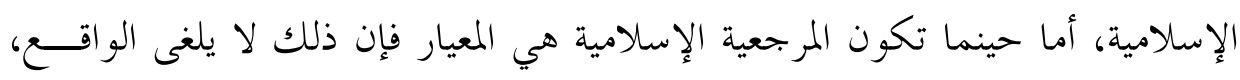

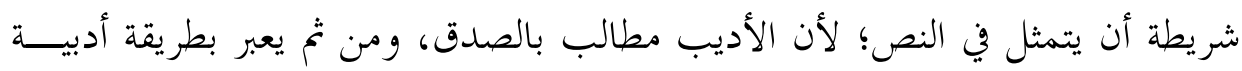

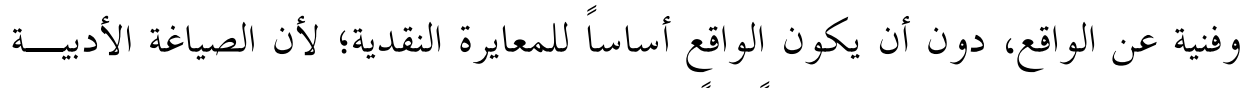

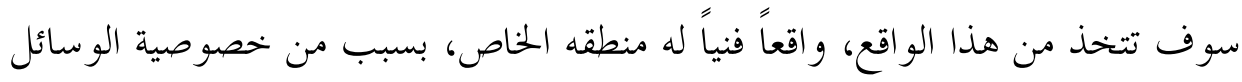

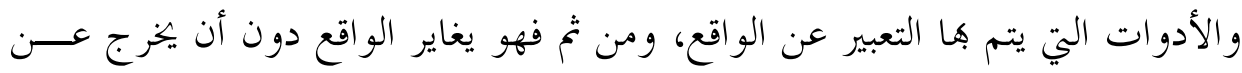

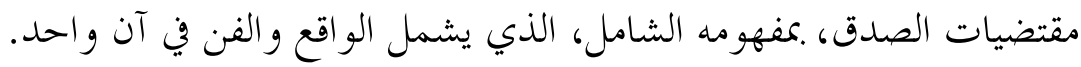


وعلى هذا فإن بريغش يتحدث عن الالتزام بثلاثة معان: التعــبير عــن قضـــايا المسلمين، والتحدث ضمن المفاهيم الإسلامية، والانسجام مع التصـــور الإســلامي،

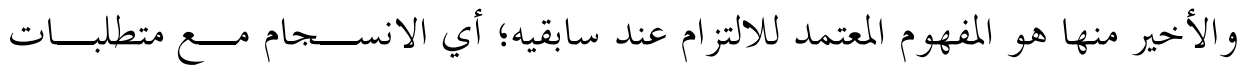

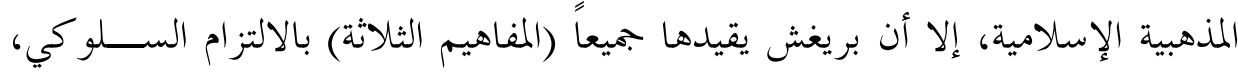

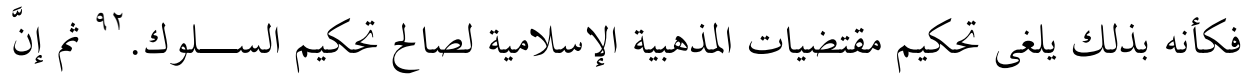

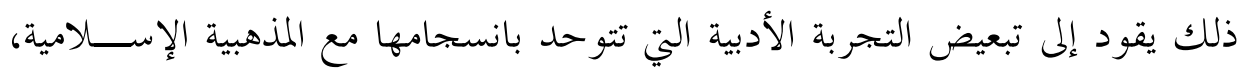

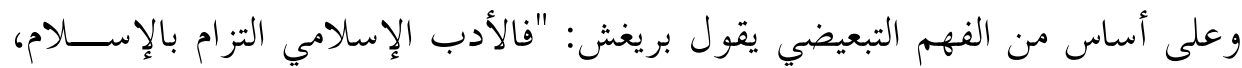

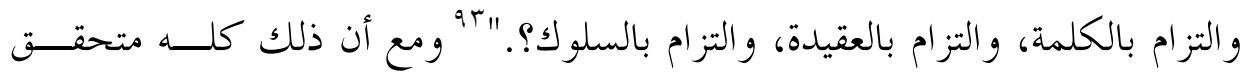

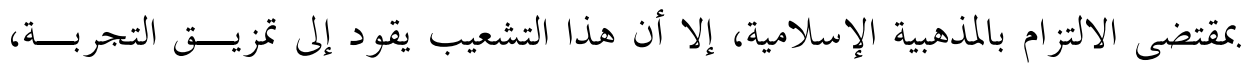

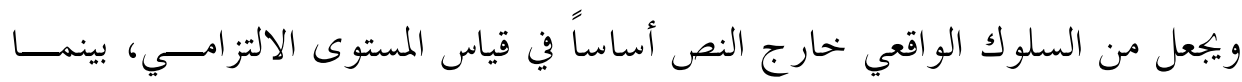

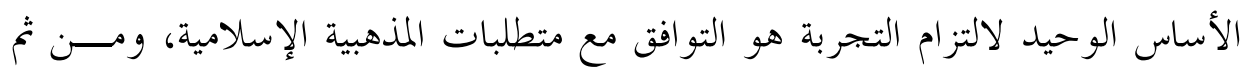

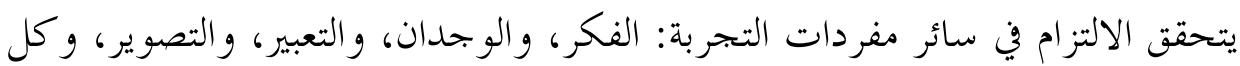

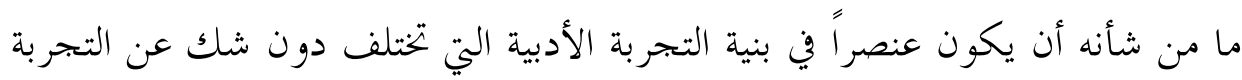

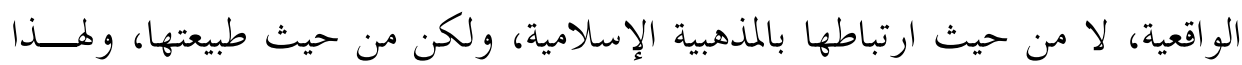

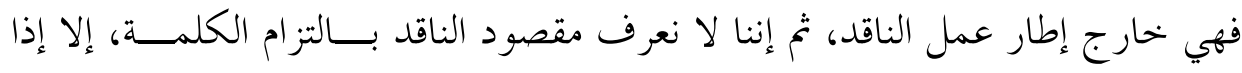

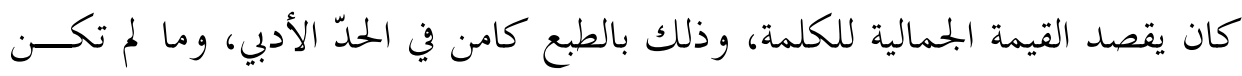
التجربة متحققة بالشرط الجمالي فهي خارج إطار الأدب، ولذا فلا يصح الحلديث عن

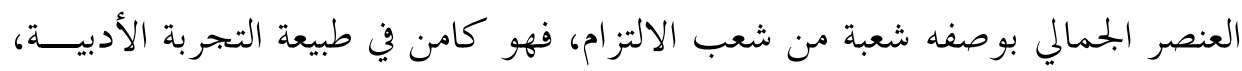
والحديث عنه إنما يكون في هذا الإطار.

وعلى نحو ما فعل بريغش، يحاول عدنان النحوي ؟َ أن يربط الالتــزام الأدبي في

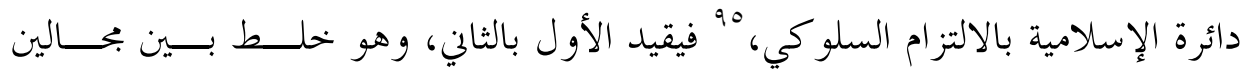

rو هل يمكن أن نتخذ من الانخرافات السلو كية عند أحمد شوقي إن صدق حافظ إبراهيم فيما يرويه عنه، أساسـاً

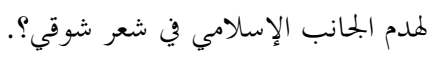

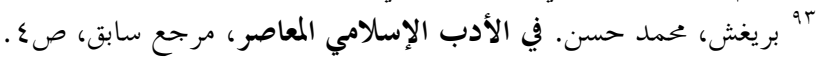

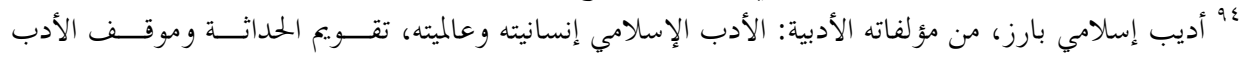

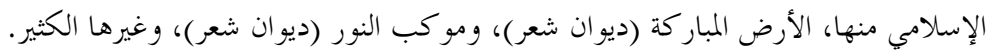




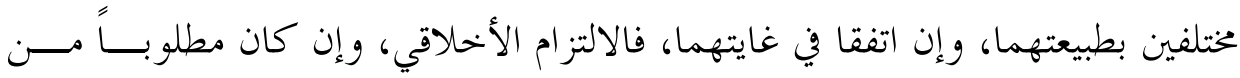

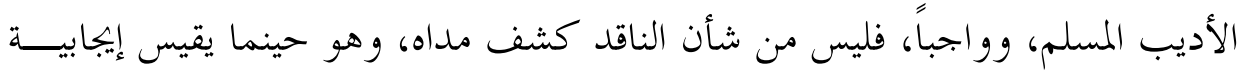
القيم الأخلاقية في بنية التجربة الأدبية، فإنما يقيسها بالمذهبية الإسلامية، ومدى اتفيات اتفاقها

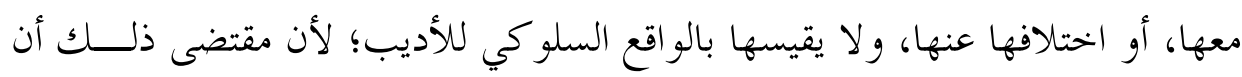
״يجعل من واقع الفرد مرجعية، وهو خطأ لا يحتاج إلى بيان.

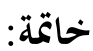

من الملحوظ من خحلال هذا العرض لبعض بحالات الاستخدام لمصطلح الالتــزام،

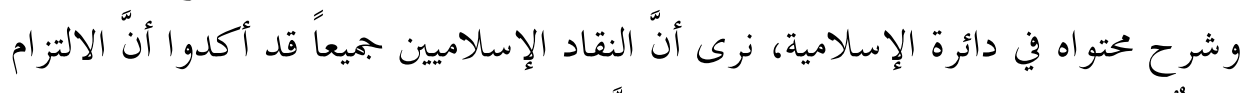

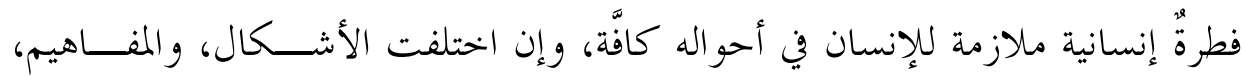
وعلى هذا فإنَّ المصطلح (ملتزم) ينصرف إلى الأديب، لا إلى الأدب، و لا يمكن للأديب

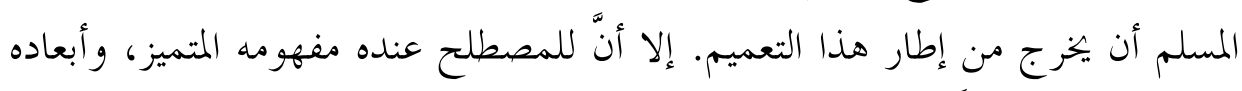

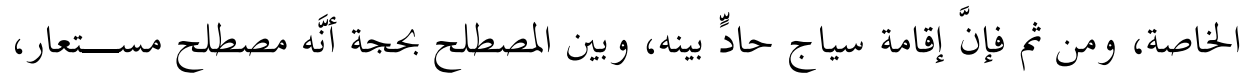
هو خروج حاد على منطق الواقع، ومصادمة لحقائقه المقررة.

و كذلك شدد النقاد الإسلاميون على أنَّ الالتزام بمفهومه الإسلامي نابع من ذات

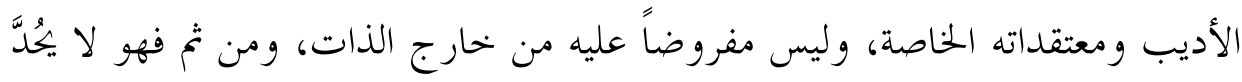

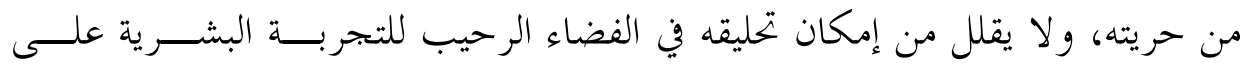

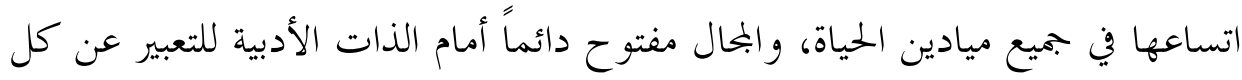
ما يمس الحياة الخاصة، و العامة لهذه الذات، ودائرة الصياغة الأدبية مفتو حة أمام الأديب

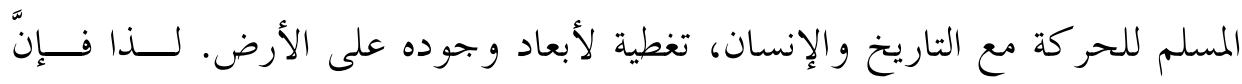

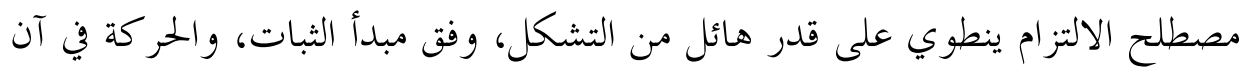

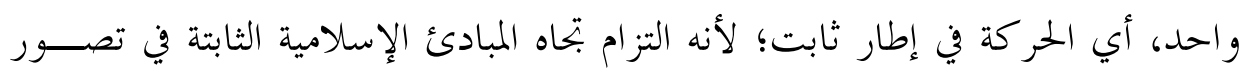

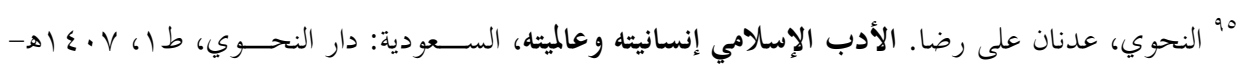




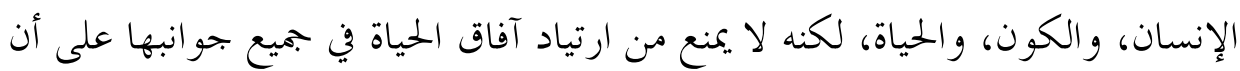
يتم ذلك في ضوء تلك المبادئ الثابتة.

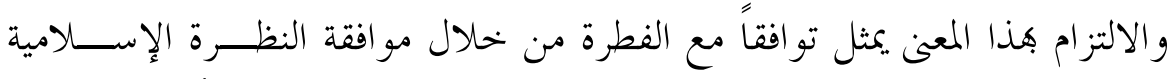

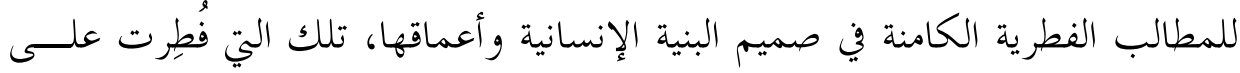

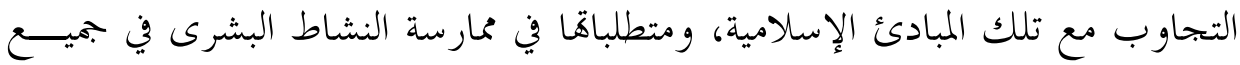

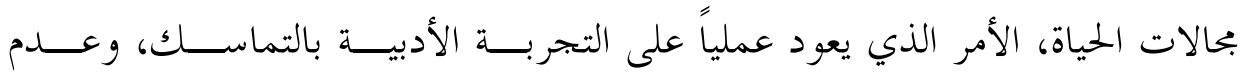

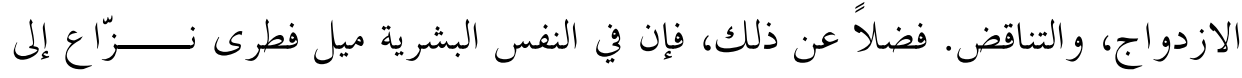

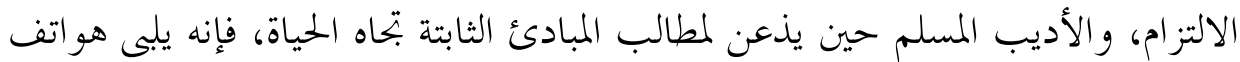

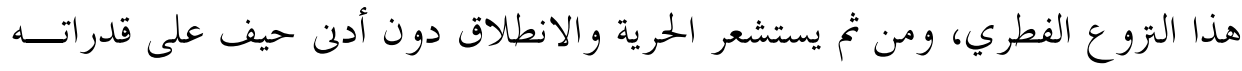

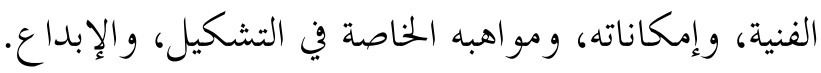
وعلى الرغم من التأثيرات السلبية للمصطلح، تلك التي أشرنا إليها، التي ظهــرت

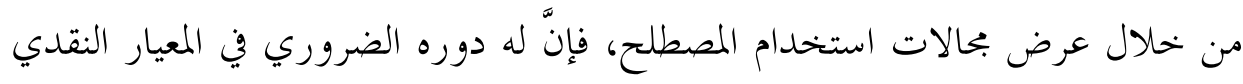

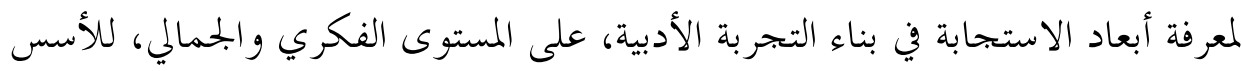

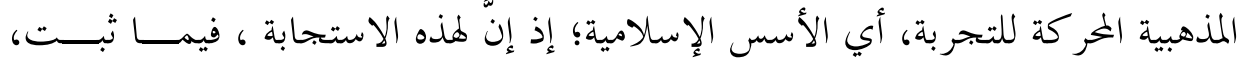

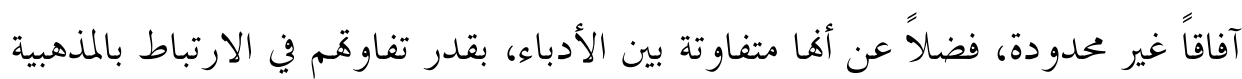

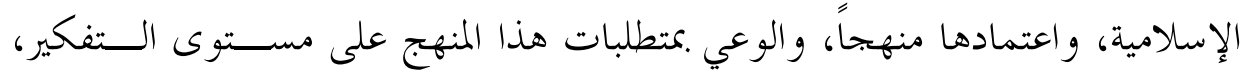

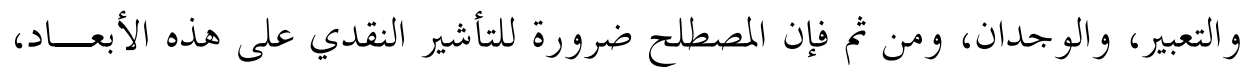

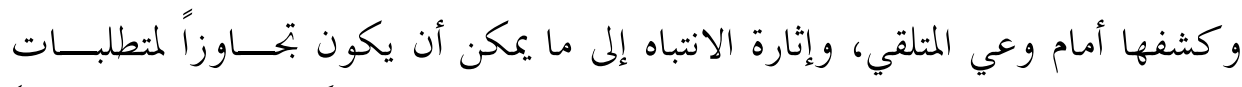

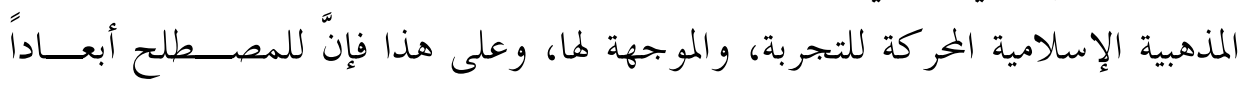

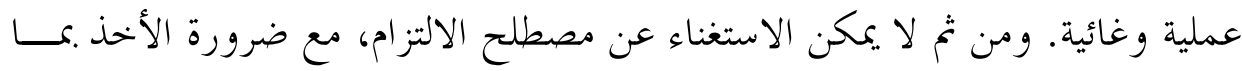

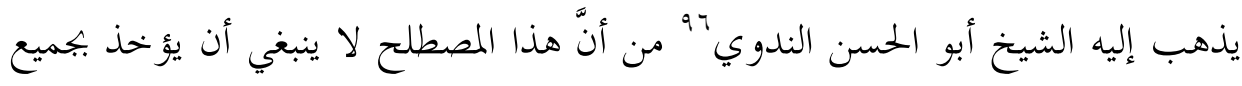

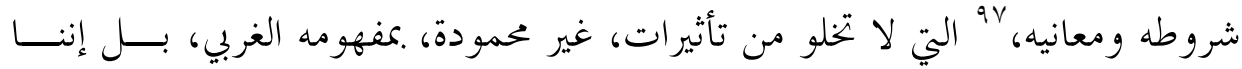

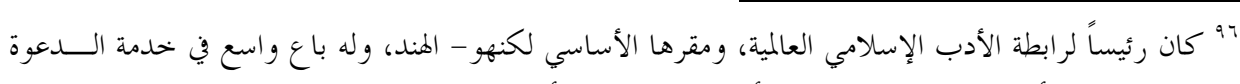

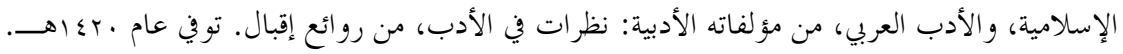

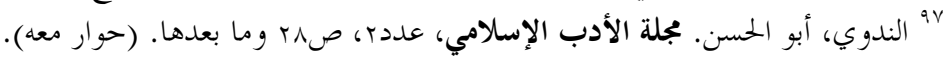




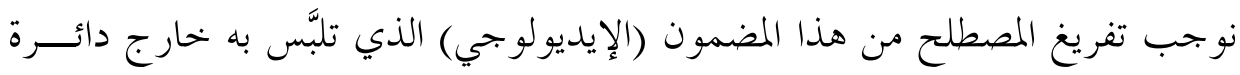

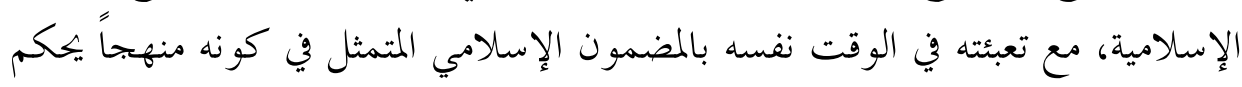

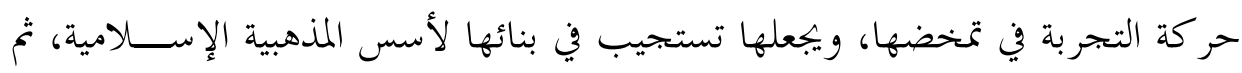

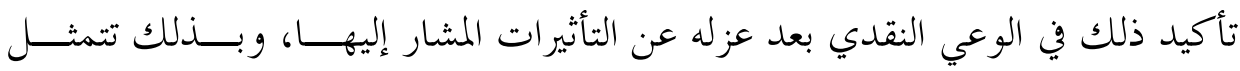

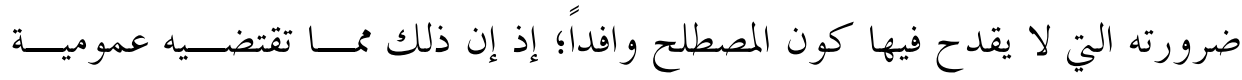

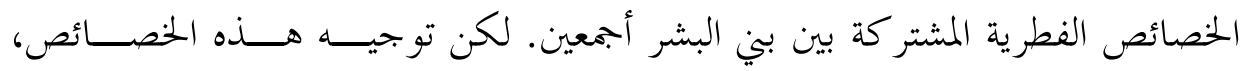

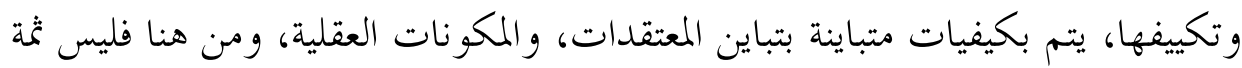

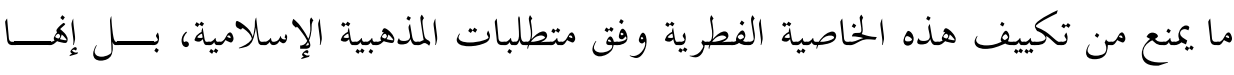

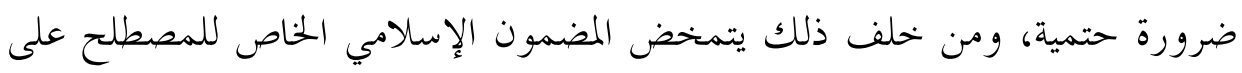

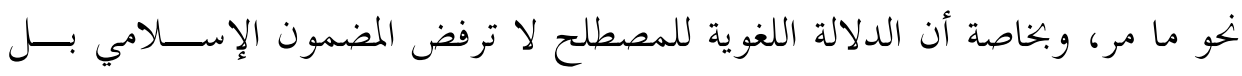
تؤ ازره، وتمنحه تميزه وخصصو صيته.

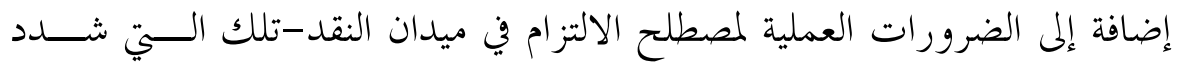

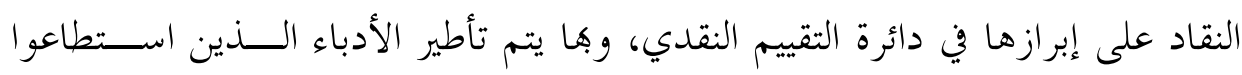

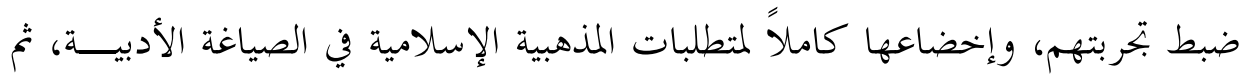

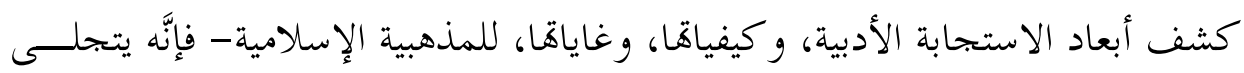

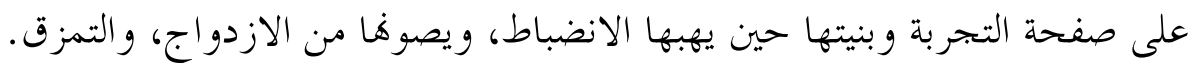

